\title{
Centrais sindicais: histórico e constitucionalidade
}

\author{
Nelson A. Jobim \\ Rodrigo de Oliveira Kaufmann
}

\section{SUMÁRIO EXECUTIVO}

Centrais Sindicais e CF

Centrais Sindicais e representação dos trabalhadores

Contribuição sindical. Repartição dos recursos

Tribunal de Contas da União

Convenção 87 da OIT

\section{HISTÓRIA}

I. Introdução

II. O sindicalismo anárquico no Brasil até 1930

III. O sindicalismo na época de Vargas

(1) Nacionalismo e peleguismo

(2) O Decreto 19.770, de 19.3.1931

(3) A Constituição de 1934 e o Decreto 24.694, de 12.7.1934

(4) A Constituição de 1937 e o Decreto-Lei 1.402, de 5.7.1939

(5) O Imposto Sindical e a CLT

IV. A Constituição de 1946 e a reação dos sindicatos ao controle do poder público

V. O sindicalismo no segundo governo de Vargas

VI. Sindicalismo no período do regime militar

VII. A década de 1990 e o novo modelo das centrais sindicais

VIII. Notas conclusivas da parte histórica 


\section{DIREITO}

Constitucionalidade da Lei 11.648, de 31.3.2008

I. Introdução

II. ADI no 4.067. Pontos da petição inicial

III. A constitucionalidade da Lei 11.648, de 31.3.2008

(1) As centrais sindicais como realidade inafastável

(2) A compatibilidade com a Convenção 87 da OIT

(3) O sentido de "categoria profissional" para o sindicalismo moderno

(4) A redistribuição da contribuição sindical

(A) O regime inicial do imposto sindical

(B) O regime da CLT para o imposto sindical

(C) Alterações na aplicação dos recursos do imposto sindical após 1964

(D) Novo regime de divisão da arrecadação da contribuição sindical

IV. Estado do julgamento no STF

Representatividade

Redistribuição de parcela dos recursos

Tribunal de Contas da União

V. Conclusão

\section{SUMÁRIO EXECUTIVO}

[Centrais Sindicais e CF]

(01) As CENTRAIS SINDICAIS surgem, com força, no início da década de 1990. São uma etapa do processo de evolução da representação dos trabalhadores na busca de sua autonomia e da garantia da liberdade de associação sindical (CF, art. 8ํㅜ caput, I e V);

(02) A REABERTURA DEMOCRÁTICA exige compreensão atualizada do direito sindical, imposta pelas noções de LIBERDADE ASSOCIATIVA (CF, art. 5, XVII, XVIII e XXI), LIBERDADE DE ASSOCIAÇÃO SINDICAL (CF, art. $8^{\circ}$, caput) e DIREITO DE PARTICIPAÇÃO dos trabalhadores nos colegiados de órgãos públicos (CF, art. 10);

(03) Quando da ELABORAÇÃO da CF DE 1988, o nascimento das CENTRAIS SINDICAIS era seminal e incipiente. Posteriormente, elas passaram a ser um fato, resultado de embates políticos típicos da história brasileira, e se afirmaram, como meio eficaz, na luta reivindicatória e nas conquistas de direitos dos trabalhadores; 
[Centrais Sindicais e representação dos trabalhadores]

(04) A UNICIDADE SINDICAL deve merecer, a partir do texto da CF de 1988, uma interpretação que acompanhe a realidade, diferenciada daquela em que foi formulada (período VARGAS);

(05) Uma interpretação restrita e fechada da expressão "CATEGORIA PROFISSIONAL OU ECONÔMICA" (regras sindicais - CF, art. 8o, II; e disposições tributárias - CF, art. 149) é inadequada e regressista, pois exclui e impossibilita uma compreensão da CF que abarque o processo histórico, mantendo-a aferrada ao passado;

(06) Entender que a REPRESENTAÇÃO DE CATEGORIAS PROFISSIONAIS OU ECONÔMICAS somente pode ocorrer por meio dos sindicatos da estrutura corporativa da CLT restringe os variados e não excludentes caminhos políticos e institucionais de representação dos trabalhadores. Tais caminhos são assegurados pela liberdade constitucional de associação, por meio dos quais também se dão suas conquistas e a exposição de suas reivindicações;

(07) O RECONHECIMENTO DAS CENTRAIS SINDICAIS, pela Lei 11.648/2008, assegurou a ampliação, gestada pelo movimento sindical, de mecanismo de representação, de ação política e de negociação dos trabalhadores;

(08) A MAIORIA FORMADA NO STF (6 MINISTROS) votou pela constitucionalidade da Lei, na parte em que esta assegura às CENTRAIS SINDICAIS a participação nos fóruns de negociações, sem exclusão dos sindicatos, federações e confederações ("interpretação conforme"). Esta MAIORIA admitiu a constitucionalidade do reconhecimento das CENTRAIS como instituições de representação dos interesses dos trabalhadores, sem exclusão de outras;

(09) O fato de serem ENTIDADES HORIZONTAIS e se localizarem fora da estrutura sindical da CLT, não impressionou a MAIORIA, pois ela entendeu constitucional a atribuição, às CENTRAIS SINDICAIS, da representação dos direitos e interesses coletivos ou individuais das categorias referentes aos sindicatos a elas filiados (em respeito ao art. $8^{\circ}$, III, da CF);

[Contribuição sindical. Repartição dos recursos]

(10) A CONTRIBUIÇÃO SINDICAL foi criada como imposto sindical pelo Decreto-Lei 2.377, 8.7.1940;

(11) O histórico da REPARTIÇÃO DOS RECURSOS da contribuição sindical demonstra que, até a Lei 11.648/2008, um percentual de $20 \%$ era destinado 
ao GOVERNO FEDERAL, como reforço orçamentário do MINISTÉRIO DO TRABALHO e para as políticas de assistência ao desemprego, que não se confundem com o FAT;

(12) A Lei 11.648/2008 não alterou a PARTICIPAÇÃO DOS SINDICATOS, FEDERAÇÕES E CONFEDERAÇÕES (estrutura da CLT) na repartição dos recursos da contribuição sindical;

(13) A PARTICIPAÇÃO DAS CENTRAIS SINDICAIS, na distribuição dos recursos oriundos da contribuição sindical, é consequência necessária do reconhecimento de que elas também atuam na defesa das categoriais profissionais e econômicas representadas pelos sindicatos a elas filiados, sem a exclusão das demais associações;

(14) A PARCELA atribuída pela Lei às CENTRAIS SINDICAIS fazia parte do percentual que era destinado ao GOVERNO FEDERAL. Tal percentual nunca teve qualquer utilização dirigida a determinada categoria profissional ou econômica, como é de sua história;

(15) A DESTINAÇÃO DO PERCENTUAL, de onde é extraída a parcela atribuída às CENTRAIS SINDICAIS, desautoriza o argumento de que as CENTRAIS SINDICAIS não poderiam recebê-la por não representarem categorias profissionais específicas;

[Tribunal de Contas da União]

(16) Como consequência do regime imposto pela CF (art. 70, parágrafo único, e art. 37, caput), os SINDICATOS, FEDERAÇÕES, CONFEDERAÇÕES e CENTRAIS SINDICAIS, que recebem parcela de arrecadação da contribuição sindical, deveriam se submeter à fiscalização do TRIBUNAL DE CONTAS DA UNIÃO; e

[Convenção 87 da OIT]

(17) Por último, a Lei 11.648/2008 reitera a concepção da CONVENÇÃO № 87 da ORGANIZAÇÃO INTERNACIONAL DO TRABALHO (OIT) em matéria de representação dos trabalhadores, pelo que torna o movimento sindical brasileiro compatível internacionalmente. 


\section{História}

\section{Introdução}

A história do sindicalismo no Brasil é marcada por campanhas, reconhecimento e conquistas que moldaram as relações do trabalho no país.

O desenvolvimento da representação dos trabalhadores pode ser dividido em fases que caracterizam:

(1) as etapas de profissionalização e institucionalização do movimento operário; e

(2) a busca de sua independência do Estado, sua autonomia política e administrativa e seu formato democrático.

A Lei 11.648, de 31.3.2008 (reconhecimento formal das centrais sindicais), integra a fase (2) ao prestigiar organizações representativas dos trabalhadores, formadas espontaneamente, sem a indução, normativa ou financeira, do Estado.

A exata compreensão da importância dessa lei impõe um exame do histórico das representações de trabalhadores e um entendimento do momento atual.

\section{O sindicalismo anárquico no Brasil até 1930}

A história do sindicalismo brasileiro consiste em um processo de busca de representação trabalhista que, ao mesmo tempo:

(1) seja legítima;

(2) produza discurso reivindicatório de mobilização;

(3) não seja radical;

(4) sustente-se financeiramente e;

(5) estabeleça com o Poder Público relação de independência e de diálogo proativo.

O início desse processo está no $1^{\circ}$ Congresso Nacional dos Trabalhadores, realizado em 20.4.1906, e na fundação da Confederação Operária Brasileira (COB), no Rio de Janeiro.

Lá se reuniram vários sindicatos, federações, ligas e uniões operárias e duas posições colidiram:

(1) o anarcossindicalismo, que privilegiava a luta dentro da fábrica; e 
(2) o socialismo, que defendia a transformação gradativa da sociedade capitalista por meio da atuação política.

De cunho partidário e ideológico, o incipiente movimento sindical de então já anunciava o seu poder e influência.

Tal anúncio incentivou o desejo do Poder Público de acompanhá-lo de perto, controlá-lo e repreendê-lo (veja-se a Lei Adolfo Gordo, de 1907¹).

A queda abrupta de salários com a crise de produção após a 1a Guerra Mundial gerou série de greves entre 1917 e 1920.

Tal fato levou à ação repressora do Estado.

A greve de junho e julho de $1917^{2}$ parou São Paulo e movimentou 45 mil trabalhadores sob a liderança do movimento anarquista ${ }^{3}$

O governo convocou as tropas do interior e 7 mil milicianos ocuparam a cidade. Líderes sindicais e operários como o sapateiro anarquista ANTONIO MARTINEZ $^{4}$ e CONSTANTINO CASTELANI foram assassinados.

A postura anarquista e os movimentos de dispersão e isolamento entre si auxiliaram a repressão policial contra a atuação dos sindicatos.

\section{O sindicalismo na época de Vargas}

\section{(1) Nacionalismo e peleguismo}

GETÚLIO VARGAS (1930) iniciou o processo de fortalecimento do Estado Nacional, pois, dentre outras, ampliou sua política interventiva a todos os setores da economia e da sociedade.

No campo do movimento trabalhista, a política de ampliação da atuação estatal atrelou a estrutura sindical ao próprio Estado e, assim, descolou-os de suas bases sociais e políticas.

\footnotetext{
${ }^{1}$ L. 1.641, de 7.1.1907, proposta pelo Deputado Adolfo Gordo, de São Paulo. Estabelecia regras de expulsão do país de estrangeiro que "por qualquer motivo, comprometer a segurança nacional ou a tranquilidade pública" foi largamente utilizada para reprimir greves e movimentos operários de forte influência italiana.

${ }^{2}$ Fábricas têxteis, na Moóca e Ipiranga.

3 O anarquismo se pautava na orientação filosófica e ideias dos russos MIKHAIL ALEKSANDROVITCH BAKUNIN (1814-1876) e PIOTR KROPOTKIN (1842-1921) e no francês PIERRE-JOSEPH PROUDHON (1809-1865). O anarquismo, de forma geral, é contrário a toda forma de governo, visando a implantação de uma sociedade igualitária, antecedida da destruição do Estado capitalista, em que a distribuição de bens se dá pelo critério da necessidade. Entende o Estado como invenção burguesa e negam qualquer forma de poder institucionalizado.

${ }^{4}$ Tecelão do Cotonifício Crespi, de São Paulo.
} 
Em realidade, VARGAS, que conquista o poder pelo Movimento de 30, se sustentou na superação política das velhas oligarquias enfraquecidas pela crise de 1929.

Sua bandeira foi o nacionalismo que aglutinou, para o apoio do seu Governo, grupo bastante heterogêneo:

(1) militares de baixa e média patentes;

(2) elites regionais fora do eixo São Paulo e Rio de Janeiro (Rio Grande do Sul, Paraíba etc.);

(3) empresários paulistas ligados ao Partido Democrático; e

(4) o próprio movimento operário.

A figura de GETÚLIO VARGAS ${ }^{5}$ dava unidade e força política a esse aglomerado de grupos opositores da política "café-com-leite".

O discurso nacionalista de tom conciliatório, por outro lado, teve, dentre outros, os efeitos de:

(1) aproximar os militares ao novo Governo;

(2) seduzir a classe média urbana e;

(3) atrair a população mais pobre que concorria com os imigrantes pelos empregos.

A industrialização do período havia dado novo fôlego ao movimento de trabalhadores que, organizados em sindicatos, já haviam demonstrado enorme capacidade de mobilização e força política.

Além disso, a classe operária se apresentava com grande volatilidade, liderada por anarquistas, muitos de origem italiana.

Entendia-se que a estratégia da conciliação nacional somente seria possível se essa enorme força fosse mantida sob controle e fossem enfraquecidas as teses da luta de classes e do combate ao Governo.

A forma de controlar a classe operária, submetendo-a ao projeto de conciliação e desenvolvimento nacional, se deu por meio de uma política trabalhista de domesticação conhecida por "peleguismo". 6

A expressão "pelego" passou a designar o líder sindical responsável por atenuar as relações entre Estado e trabalhadores de modo que a política governamental tivesse mais aceitação.

\footnotetext{
${ }^{5}$ Ex-deputado estadual e federal, Ministro da Fazenda no Governo de Washington Luís e Presidente do Estado do Rio Grande do Sul.

6 "Pelego" consiste no couro com a lã retirado da ovelha e que se presta ao assento do cavaleiro de maneira a amortecer o cavalgar.
} 
É nesse contexto que nasceu no país, especialmente com a Constituição de 1934, a Justiça do Trabalho, a conquista de direitos trabalhistas e a elaboração da Consolidação das Leis do Trabalho (CLT).

\section{(2) O Decreto 19.770, de 19.3.1931}

O processo de incorporação da representação trabalhista ao Estado se iniciou com o Decreto 19.770, de 19.3.1931, que regulou a sindicalização das classes patronais e operárias.

Tal decreto impôs o reconhecimento formal do sindicato pelo MINISTÉRIO DO TRABALHO, inclusive a aprovação de seus estatutos. ${ }^{7}$

Além do mais, o decreto exigia o encaminhamento de relatório dos "acontecimentos sociais", como alterações do quadro de sócios, estado financeiro da associação, modificações estatutárias etc. ${ }^{8}$

A EXPOSIÇÃO DE MOTIVOS do Decreto ${ }^{9}$ não deixa dúvidas que, por detrás dos argumentos de proteção e organização da representatividade dos trabalhadores, estava o interesse de neutralizar politicamente os sindicatos por meio de indução do Estado:

\section{(...)}

A minha experiência de três meses na nova Pasta já me deixou arraigada a convicção de que, sem a organização das classes profissionais, impossível se torna qualquer resultado apreciável na justa e necessária conjugação dos interesses patronais e proletários.

\footnotetext{
${ }^{7}$ Decreto 19.770, de 19.3.1931:

Art. 2 Constituídos os sindicatos de acordo com o artigo 1ํㅡ, exige-se ainda, para serem reconhecidos pelo Ministério do Trabalho, Indústria e Comércio, e que adquirirem, assim, personalidade jurídica, tenham aprovados pelo Ministério os seus estatutos, acompanhados de cópia autêntica da ata de instalação e de uma relação do número de sócios com os respectivos nomes, profissão, idade, estado civil, nacionalidade, residência e lugares ou empresas onde exercerem a sua atividade profissional.

${ }^{8}$ Decreto 19.770, de 19.3.1931:

Art. $4^{\circ}$ Os sindicatos, as federações e as confederações deverão, anualmente, até o mês de março, enviar ao Ministério do Trabalho, Indústria e Comércio relatório dos acontecimentos sociais, do qual deverão constar, obrigatoriamente, as alterações do quadro dos sócios, o estado financeiro da associação, modificações que, porventura, tenham sido feitas nos respectivos estatutos, além de fatos que, pela sua natureza, se possam prender a dispositivos do presente decreto.

${ }^{9}$ Elaborada pelo então Ministro do Trabalho, Indústria e Comércio, LINDOLFO COLLOR e datada de 15.3.1931.
} 
A Revolução de outubro encontrou o trabalho brasileiro na mais completa e dolorosa anarquia. De um modo geral, não há exagero em dizer-se que na situação atual do Brasil o trabalho é ainda considerado mercadoria, sujeita às flutuações da oferta e da procura. (...) no caso do Brasil, o menosprezo dos poderes públicos pelos problemas do trabalho cresce de vulto ainda se considerarmos que o nosso País está, por acordos e convenções internacionais, obrigado ao reconhecimento dessas novas diretrizes da política social.

(...)

O próprio Decreto $19.770 / 31$ proibia os sindicatos de promover "toda e qualquer propaganda de ideologias sectárias, de caráter social, político ou religioso, bem como de candidaturas a cargos eletivos, estranhos à natureza e finalidade das associações. ${ }^{10}$

\section{(3) A Constituição de 1934 e o Decreto 24.694, de 12.7.1934}

Era necessária, entretanto, a criação de organismos que mantivessem sob o controle oficial o trabalho de reivindicação dos sindicatos, de maneira a aumentar a relação de dependência entre essas entidades e o Poder Público.

É nesse contexto que é assinado o Decreto 22.132, de 25.11.1932, que “institui Juntas de Conciliação e Julgamento", ${ }^{11}$ criadas pelo MINISTÉRIO DO TRABALHO, INDÚSTRIA E COMÉRCIO.

\footnotetext{
${ }^{10}$ Decreto no $\mathbf{1 9 . 7 7 0}$, de 19.3.1931:
}

Art. 1o Terão os seus direitos e deveres regulados pelo presente decreto, podendo defender, perante o Governo da República e por intermédio do Ministério do Trabalho, Indústria e Comércio, os seus interesses de ordem econômica, jurídica, higiênica e cultural, todas as classes patronais e operárias, que, no território nacional, exercerem profissões idênticas, similares ou conexas, e que se organizarem em sindicados, independentes entre si, mas subordinada a sua constituição às seguintes condições:

(...)

f) abstenção, no seio das organizações sindicais, de toda e qualquer propaganda de ideologias sectárias, de carater social, político ou religioso, bem como de candidaturas a cargos eletivos, estranhos à natureza e finalidade das associações.

${ }^{11}$ Decreto no 22.132, de 25.11.1932:

Art. $1^{\circ}$ Os litígios oriundos de questões de trabalho, em que sejam partes empregados sindicalizados, e que não afetem a coletividade a que pertencerem os litigantes, serão dirimidos pelas Juntas de Conciliação e Julgamento, estabelecidas na presente lei, e na forma nela estatuída. 
As Juntas de Conciliação e Julgamento consistiram no embrião da JUSTIÇA DO TRABALHO, que seria criada pela Constituição de $1934{ }^{12}$

Também a Carta de 1934 estabelecia a representação classista nos tribunais. Além disso, a Constituição de 1934 manteve a sedução do movimento operário por meio da previsão de uma série de direitos trabalhistas, especialmente no art. $121 .^{13}$

\section{${ }^{12}$ Constituição de 1934:}

Art 122 - Para dirimir questões entre empregadores e empregados, regidas pela legislação social, fica instituída a Justiça do Trabalho, à qual não se aplica o disposto no Capítulo IV do Título I.

\section{${ }^{13}$ Constituição de 1934:}

Art 121 - A lei promoverá o amparo da produção e estabelecerá as condições do trabalho, na cidade e nos campos, tendo em vista a proteção social do trabalhador e os interesses econômicos do País.

§ 1ํ - A legislação do trabalho observará os seguintes preceitos, além de outros que colimem melhorar as condições do trabalhador:

a) proibição de diferença de salário para um mesmo trabalho, por motivo de idade, sexo, nacionalidade ou estado civil;

b) salário mínimo, capaz de satisfazer, conforme as condições de cada região, às necessidades normais do trabalhador;

c) trabalho diário não excedente de oito horas, reduzíveis, mas só prorrogáveis nos casos previstos em lei;

d) proibição de trabalho a menores de 14 anos; de trabalho noturno a menores de 16 e em indústrias insalubres, a menores de 18 anos e a mulheres;

e) repouso hebdomadário, de preferência aos domingos;

f) férias anuais remuneradas;

g) indenização ao trabalhador dispensado sem justa causa;

h) assistência médica e sanitária ao trabalhador e à gestante, assegurando a esta descanso antes e depois do parto, sem prejuízo do salário e do emprego, e instituição de previdência, mediante contribuição igual da União, do empregador e do empregado, a favor da velhice, da invalidez, da maternidade e nos casos de acidentes de trabalho ou de morte;

i) regulamentação do exercício de todas as profissões;

j) reconhecimento das convenções coletivas, de trabalho.

$\S 2^{\circ}$ - Para o efeito deste artigo, não há distinção entre o trabalho manual e o trabalho intelectual ou técnico, nem entre os profissionais respectivos.

$\S 3^{\circ}$ - Os serviços de amparo à maternidade e à infância, os referentes ao lar e ao trabalho feminino, assim como a fiscalização e a orientação respectivas, serão incumbidos de preferência a mulheres habilitadas.

$\S 4^{\circ}-\mathrm{O}$ trabalho agrícola será objeto de regulamentação especial, em que se atenderá, quanto possível, ao disposto neste artigo. Procurar-se-á fixar o homem no campo, cuidar da sua educação rural, e assegurar ao trabalhador nacional a preferência na colonização e aproveitamento das terras públicas.

$\S 5^{\circ}$ - A União promoverá, em cooperação com os Estados, a organização de colônias agrícolas, para onde serão encaminhados os habitantes de zonas empobrecidas, que o desejarem, e os sem trabalho.

$\S 6^{0}-$ A entrada de imigrantes no território nacional sofrerá as restrições necessárias à garantia da integração étnica e capacidade física e civil do imigrante, não podendo, porém, a corrente imigratória de cada país exceder, anualmente, o limite de dois por cento sobre o número total dos respectivos nacionais fixados no Brasil durante os últimos cinquenta anos. 
O texto da Constituição, durante os debates legislativos, assegurava a PLURALIDADE SINDICAL e a autonomia dos sindicatos (art. 120, parágrafo único), por sugestão do DEPUTADO TRISTÃO ATHAYDE, em claro sinal de que a política de controle sindical poderia retroagir.

Entretanto, o Governo Federal, já por meio do Decreto 24.694, de 12.7.1934 - portanto, antes da promulgação da Constituição - estabeleceu outro regramento ao dispor sobre os "sindicatos profissionais".

Tal Decreto, de modo geral, "instituía" os sindicatos. ${ }^{14}$

Tratava os sindicatos como criações do Poder Público e estabelecia:

(1) suas prerrogativas;

(2) suas obrigações;

(3) a forma como se relacionariam com o Estado;

(4) a forma de constituição e de funcionamento;

(5) a estrutura piramidal de organização da representação dos trabalhadores; ${ }^{15}$ e, por fim;

(6) exigência dos sindicatos, federações e confederações serem reconhecidos pelo MINISTÉRIO DO TRABALHO. ${ }^{16}$

§7으 - É vedada a concentração de imigrantes em qualquer ponto do território da União, devendo a lei regular a seleção, localização e assimilação do alienígena.

$\S 8^{\circ}$ - Nos acidentes do trabalho em obras públicas da União, dos Estados e dos Municípios, a indenização será feita pela folha de pagamento, dentro de quinze dias depois da sentença, da qual não se admitirá recurso ex officio.

${ }^{14}$ Decreto no 24.694, de 12.7.1934:

Art. 1o Ficam, pelo presente decreto, instituídos os sindicatos como tipos específicos de organização das profissões que, no território nacional, tiverem por objeto a atividade lícita, com fins econômicos, de qualquer função ou mister.

${ }^{15}$ Decreto no 24.694, de 12.7.1934:

Art. 24. Os sindicatos de empregadores ou de empregados, com sede num mesmo município, poderão formar uniões, destinadas a coordenar os interesses gerais das respectivas profissões.

Art. 25. É facultado aos sindicatos, quando em número não inferior a três e pertencentes ao mesmo grupo profissional, formar federações, independentes entre si.

Parágrafo único. As federações a que se refere este artigo serão estaduais e, na impossibilidade, poderão ser regionais ou nacional.

Art. 26. Organizando-se, pelo menos, três federações, poderão estas constituir uma confederação com sede na Capital da República.

${ }^{16}$ Decreto no 24.694, de 12.7.1934:

Art. 28. O pedido de reconhecimento, perante o Ministério do Trabalho, Indústria e Comércio, de uma união de uma federação ou de uma confederação deverá ser acompanhado, além dos respectivos estatutos, de cópias autenticadas das atas de instalação e da assembleia geral de cada sindicato, ou de cada federação que autorizar a filiação.

(...)

$\S 3$ As uniões, as federações e as confederações só poderão funcionar depois de reconhecidas pelo Ministério do Trabalho, Indústria e Comércio. 
O Decreto 24.694/34 foi o marco da domesticação dos sindicatos e da subordinação de seu funcionamento às regras fixadas pelo Poder Público.

Esse modelo de controle estatal se perpetuou e, somente nos anos 19801990, o quadro começou a se alterar com a criação das CENTRAIS SINDICAIS.

O país caminhava para uma longa tradição baseada no princípio da UNICIDADE SINDICAL, que mais tarde seria consagrada na Constituição de 1937 e na CLT.

De fato, o modelo da PLURALIDADE SINDICAL ${ }^{17}$ é, naquele momento, comumente apontado, não como indício da libertação do movimento operário das tentativas de controle do Estado, mas como instrumento do movimento católico ${ }^{18}$ para enfraquecer os sindicatos por meio da promoção das disputas internas e da concorrência entre representações de trabalhadores e evitar o fortalecimento do Estado como agente interlocutor controlador das demandas sociais.

Lê-se em LUIZ WERNECK VIANNA:

\section{(...)}

O advento do Estado fascista inaugura uma nova ameaça, integrandoas ao aparato do Estado e realizando sob forma secular as propostas substantivas contidas na doutrina social da Igreja. A "publicização" dos sindicatos rompe o elo que a unia às classes subalternas, esvaziando as possibilidades do exercício dos novos papéis que procurava assumir. Sua reação se dirige, então, no sentido de condenar a repressão da livre vida associativa sob o Estado Corporativo $(. . .)^{19}$

\footnotetext{
${ }^{17}$ Preconizado no então parágrafo único do art. 120 do Texto não definitivo da Constituição de 1934.

${ }^{18}$ Com o enfraquecimento tradicional do catolicismo, especialmente na década de 1920 com a urbanização e secularização da cultura, o arcebispo do Rio de Janeiro, DOM SEBASTIÃO LEME, foi o artífice de um movimento de tentativa de recuperação do prestígio perdido da Igreja. Nessa linha, fundou a revista A ORDEM (1921) e o CENTRO DOM VITAL (1922) sob a direção de JACKSON DE FIGUEIREDO. Em 1932, esse grupo católico funda a LIGA ELEITORAL CATÓLICA (LEC) sob a secretaria-geral de ALCEU AMOROSO LIMA, de maneira a imprimir ação política ao movimento. A LEC conseguiu eleger número destacado de representantes para a Assembleia Nacional Constituinte de 1933-1934 (nomes como LUÍS SUCUPIRA, ANES DIAS, PLÍNIO CORREIA DE OLIVEIRA e MORAIS ANDRADE) e obteve importantes vitórias como a promulgação da Constituição em nome de Deus (preâmbulo), o direito do ensino religioso nas escolas públicas mesmo de frequência facultativa (art. 153) e o veto ao divórcio por meio da previsão constitucional do "desquite" (art. 144, parágrafo único). Sobre a estratégia do "poder indireto", ver VIANNA, Luís Werneck. Liberalismo e sindicato no Brasil. 2. ed. Rio de Janeiro: Editora Paz e Terra, 1978. p. 164.

${ }^{19}$ Ibid., p. 163.
} 
A UNICIDADE SINDICAL trouxe, portanto, naquele contexto, o grande benefício de fortalecer e oficializar a representatividade dos operários, mesmo que por meio de uma estrutura subordinada ao Poder Público, já com os traços do "peleguismo".

Entretanto, também para VARGAS, o fortalecimento do movimento de trabalhadores não era politicamente conveniente.

Por isso, apesar da garantia da UNICIDADE SINDICAL, a "Pirâmide Sindical" seria organizada por categorias profissionais.

Evitava-se, assim, a reunião das forças e do poder reivindicatório dos trabalhadores das mais diversas categorias.

A organização da representação sindical por categorias profissionais, portanto, pode perfeitamente ser vista como uma diluição da representatividade operária perante seus empregadores e perante o Poder público.

\section{(4) A Constituição de 1937 e o Decreto-Lei 1.402, de 5.7.1939}

A Constituição outorgada de 1937, que representou a centralização do poder com GETÚLIO VARGAS e a radicalização da política de intervenção na economia, tornou expressos os limites exíguos da liberdade sindical.

Em realidade, ficou explícita a contradição:

- de um lado, era assegurada a liberdade da associação sindical;

- de outro, só se atribuía o direito de representação aos sindicatos reconhecidos pelo Estado. ${ }^{20}$

A Carta também fortaleceu outros instrumentos que mantinham o movimento sindical sob o controle do Poder Público ao repetir o dispositivo da Constituição de 1934 que instituía a Justiça do Trabalho, atrelada ao MINISTÉRIO DO TRABALHO (art. 122, caput).

É importante lembrar que a Constituição de 1937 confirmou os direitos trabalhistas anteriormente estabelecidos na Constituição de 1934 como o salário mínimo, férias anuais e o descanso semanal.

\section{${ }^{20}$ Constituição de 1937:}

Art. 138 - A associação profissional ou sindical é livre. Somente, porém, o sindicato regularmente reconhecido pelo Estado tem o direito de representação legal dos que participarem da categoria de produção para que foi constituído, e de defender-lhes os direitos perante o Estado e as outras associações profissionais, estipular contratos coletivos de trabalho obrigatórios para todos os seus associados, impor-lhes contribuições e exercer em relação a eles funções delegadas de Poder Público. 
O fortalecimento do MINISTÉRIO DO TRABALHO se transformou em medida essencial para a construção da imagem de VARGAS como o "pai dos pobres".

Já no início da década de 1940, a estratégia para a construção da imagem de GETÚLIO VARGAS se intensifica com o MINISTRO MARCONDES FILHO e com o uso de instrumentos de divulgação como a "Hora do Brasil" e a comemoração do dia 1ำ de maio (Dia do Trabalho), com a participação do próprio PRESIDENTE DA REPÚBLICA.

A "ideologia do trabalhismo" fortalecia-se.

Muito mais do que garantir fortalecimento e autonomia dos sindicatos, a política varguista era, ao contrário, de monitorá-los de perto, atenuando o poder ideológico de seu discurso e a força de sua ação política.

Isso parece estar bem evidenciado com a regra da proibição da realização de greves por serem "incompatíveis com os superiores interesses da produção nacional". ${ }^{21}$

Dois anos depois, essa opção política se reafirma com a edição do Decretolei (DL) 1.402, de 5.7.1939, que regulou a associação em sindicatos.

A mesma contradição constante da Constituição de 1937 se mantém.

Enquanto garante liberdade associativa, ${ }^{22}$ o DL cria o registro das associações profissionais no Departamento Nacional do Trabalho e nas Inspetorias Regionais do MINISTÉRIO DO TRABALHO. ${ }^{23}$

Tal registro era condição necessária para o reconhecimento da sua existência jurídica e representatividade política. ${ }^{24}$

\section{${ }^{21}$ Constituição de 1937:}

Art. 139 - Para dirimir os conflitos oriundos das relações entre empregadores e empregados, reguladas na legislação social, é instituída a Justiça do Trabalho, que será regulada em lei e à qual não se aplicam as disposições desta Constituição relativas à competência, ao recrutamento e às prerrogativas da Justiça comum.

A greve e o lockout são declarados recursos antissociais nocivos ao trabalho e ao capital e incompatíveis com os superiores interesses da produção nacional.

${ }^{22}$ Decreto-Lei no 1.402 , de 5.7.1939:

Art. 1o É lícita a associação, para fins de estudo, defesa e coordenação dos seus interesses profissionais, de todos os que, como empregadores, empregados ou trabalhadores por conta própria, intelectuais, técnicos ou manuais, exerçam a mesma profissão, ou profissões similares ou conexas. ${ }^{23}$ Decreto-Lei no 1.402, de 5.7.1939:

Art. 48. Fica criado, no Departamento Nacional do Trabalho e nas Inspetorias Regionais do Ministério do Trabalho, Indústria e Comércio, o registo das associações profissionais. Somente depois do registo as associações dessa natureza adquirirão personalidade jurídica.

${ }^{24}$ Decreto-Lei no ${ }^{\circ}$ 1.402, de 5.7.1939:

Art. $2^{\circ}$ Somente as associações profissionais constituídas para os fins do artigo anterior e registradas de acordo com o art. 48 poderão ser reconhecidas como sindicatos e investidas nas prerrogativas definidas nesta lei. 
Também é esse DL que primeiro traz o enunciado do chamado princípio da UNICIDADE SINDICAL.

Previa que "não será reconhecido mais de um sindicato para cada profissão" (art. 6º), ficando sob a responsabilidade do MINISTÉRIO DO TRABALHO a delimitação da base territorial do sindicato (art. $7^{\circ}, \S 1^{025}$ ).

O quadro de atividades e profissões para o registro das associações profissionais e enquadramento sindical é feito por meio do Decreto-Lei 2.381, de 9.7.1940.

\section{(5) O imposto sindical e a CLT}

Para sustentar essa estrutura sindical semiestatal, o Governo VARGAS criou o "imposto sindical" - contribuição sindical compulsória correspondente a um dia de salário que o trabalhador, sindicalizado ou não, pagaria ao sindicato. ${ }^{26}$

Pela sistemática do DL, 20\% da arrecadação seria destinada às "associações profissionais de grau superior". ${ }^{27}$

A criação do imposto sindical ofereceu condições de sustentação financeira às representações, especialmente diante do problema comum na história do trabalho no Brasil do baixo índice de sindicalização.

Por outro lado, a contribuição compulsória acabou por alimentar os chamados "sindicatos de fachada" ou "sindicatos fantasmas", problema que até hoje enfraquece o movimento sindical no país.

\section{${ }^{25}$ Decreto-Lei no ${ }^{0}$.402, de 5.7.1939:}

Art. 7으 Os sindicatos poderão ser distritais, municipais, intermunicipais, estaduais e interestaduais. Excepcionalmente, e atendendo às peculiaridades de determinadas profissões, o Ministro do Trabalho, Indústria e Comércio poderá autorizar a formação de sindicatos nacionais.

$\S 11^{\circ}$ O Ministro do Trabalho, Indústria e Comércio, na carta de reconhecimento, delimitará a base territorial do sindicato.

${ }^{26}$ Decreto-Lei no 2.377, de 8.7.1940:

Art. $2^{\circ} \mathrm{O}$ imposto sindical é devido, por todos aqueles que participarem de uma determinada categoria econômica ou profissional, em favor da associação profissional legalmente reconhecida como sindicato representativo da mesma categoria.

Art. $3^{\circ} \mathrm{O}$ imposto sindical será pago de uma só vez, anualmente, e consistirá:

a) na importância correspondente à remuneração de um dia de trabalho, para os empregados, qualquer que seja a forma da referida remuneração.

${ }^{27}$ Decreto-Lei no 2.377, de 8.7.1940:

Art. 15. Da importância anual da arrecadação do imposto sindical será deduzida, em favor das associações profissionais de grau superior, a percentagem de $20 \%$ (vinte por cento), na forma que estabelecer o Ministro do Trabalho, Indústria e Comércio. 
Com a criação da JUSTIÇA DO TRABALHO (1.5.1941), já na gestão do MINISTRO VALDEMAR FALCÃO, abria-se a porta para a necessidade de organização da legislação trabalhista, especialmente por provocação de ALEXANDRE MARCONDES FILHO, MINISTRO DO TRABALHO, INDÚSTRIA E COMÉRCIO a partir de 29.12.1941.

Com o objetivo de sistematizar a legislação caótica e desorganizada de direito do trabalho, GETÚLIO VARGAS nomeou, em janeiro de 1942, uma COMISSÃO ${ }^{28}$ encarregada de elaborar anteprojeto de unificação da legislação trabalhista.

A CONSOLIDAÇÃO DAS LEIS DO TRABALHO (CLT) foi aprovada pelo DL 5.452 (1.5.1943), nos moldes da "Carta del Lavoro" (1927) de BENITO MUSSOLINI.

A lógica era do "corporativismo", segundo a qual as associações patronais e sindicatos se organizavam e atuavam para o bem da coletividade.

Para os fins deste estudo, a CLT eternizou o modelo sindical implementado por VARGAS durante o Estado Novo:

(1) confirmação da UNICIDADE SINDICAL (art. 516 ${ }^{29}$ );

(2) a organização sindical em formato de pirâmide (art. 533, 534 e 535²);

\footnotetext{
${ }^{28}$ Formada por JOSÉ DE SEGADAS VIANA, OSCAR SARAIVA, LUÍS AUGUSTO REGO MONTEIRO, DORVAL LACERDA MARCONDES e ARNALDO LOPES SÜSSEKIND.

${ }^{29}$ CLT (Decreto-Lei no 5.452, de 1‥5.1943) - REDAÇÃO ORIGINAL:
}

Art. 516. Não será reconhecido mais de um sindicato representativo da mesma categoria econômica ou profissional, ou profissão liberal, em uma dada base territorial.

${ }^{30}$ CLT (Decreto-Lei no 5.452, de 1‥5.1943) - REDAÇÃO ORIGINAL:

Art. 533. Constituem associações sindicais de grau superior as federações e confederações organizadas nos termos desta lei.

Art. 534. É facultado aos sindicatos, quando em número não inferior a cinco representando um grupo de atividades ou profissões idênticas, similares ou conexos, organizarem-se em federação. $\S 1^{\circ}$ As federações serão constituídas por Estados, podendo o Ministro do Trabalho, Indústria e Comércio autorizar a constituições de federações interestaduais ou nacionais.

$\S 2^{o}$ É permitido a qualquer federação para o fim de lhes coordenar os interesses, agrupar os sindicatos de determinado município ou região a ela filiados; mas a união não terá direito de representação das atividades ou profissões agrupadas.

Art. 535. As confederações organizar-se-ão com o mínimo de três federações e terão sede na Capital da República.

$\S 1$ o As confederações formadas por federações de sindicatos de empregadores denominar-seão: Confederação Nacional da Indústria, Confederação Nacional do Comércio, Confederação Nacional de Transportes Marítimos, Fluviais e Aéreos, Confederação Nacional de Transportes Terrestres, Confederação Nacional de Comunicações e Publicidade, Confederação Nacional das Empresas de Crédito e Confederação Nacional de Educação e Cultura.

$\S 2^{\circ}$ As confederações formadas por federações de sindicatos de empregados terão a denominação de: Confederação Nacional dos Trabalhadores na Indústria, Confederação Nacional dos Trabalhadores no Comércio, Confederação Nacional dos Trabalhadores em Transportes Marítimos, Fluviais e Aéreos, Confederação Nacional dos Trabalhadores em Transportes Terrestres, 
(3) proibição de dimensão política na atuação dos sindicatos (art. 521 "a”, art. 530, "a" e art. 555, "c"31);

(4) organização pautada na divisão por categoria profissional (art. 511, caput e $\S 2^{0^{3}}$ );

(5) imposto sindical (arts. 578 e $579^{33}$ ) e

(6) registro de sindicatos (arts. 515 e $518^{34}$ ).

Confederação Nacional dos Trabalhadores em Comunicações e Publicidade, Confederação Nacional dos Trabalhadores nas Empresas de Crédito e Confederação Nacional dos Trabalhadores em Estabelecimentos de Educação e Cultura.

§ 3ํㅡㄹ Denominar-se-á Confederação Nacional das Profissões Liberais a reunião das respectivas federações.

$\S 4^{\circ}$ As associações sindicais de grau superior da Agricultura e Pecuária serão organizadas na conformidade do que dispuser a lei que regular a sindicalização dessas atividades ou profissões.

${ }^{31}$ CLT (Decreto-Lei no 5.452, de 10.5.1943) - REDAÇÃO ORIGINAL:

Art. 521. São condições para o funcionamento do sindicato:

a) abstenção de qualquer propaganda de doutrinas incompatíveis com as instituições e os interesses da Nação, bem como de candidaturas a cargos eletivos estranhos ao sindicato;

Art. 530. Não podem ser eleitos para cargos administrativos ou de representação econômica ou profissional:

a) os que professarem ideologias incompatíveis com as instituições ou os interesses da Nação:

Art. 555. A pena de cassação da carta de reconhecimento será imposta à entidade sindical:

(...)

c) que não obedecer às normas emanadas das autoridades corporativas competentes ou às diretrizes da política econômica ditadas pelo Presidente da República, ou criar obstáculos à sua execução.

${ }^{32}$ CLT (Decreto-Lei no 5.452, de 1‥5.1943) - REDAÇÃO ORIGINAL:

Art. 511. É lícita a associação para fins de estudo, defesa e coordenação dos seus interesses econômicos ou profissionais de todos os que, como empregadores, empregados, agentes ou trabalhadores autônomos ou profissionais liberais exerçam, respectivamente, a mesma atividade ou profissão ou atividades ou profissões similares ou conexas.

(...)

$\S 2^{\circ}$ A similitude de condições de vida oriunda da profissão ou trabalho em comum, em situação de emprego na mesma atividade econômica ou em atividades econômicas similares ou conexas, compõe a expressão social elementar compreendida como categoria profissional.

${ }^{33}$ CLT (Decreto-Lei no 5.452, de 1‥5.1943) - REDAÇÃO ORIGINAL:

Art. 578. As contribuições devidas aos sindicatos pelos que participem das categorias econômicas ou profissionais ou das profissões liberais representadas pelas referidas entidades, serão, sob a denominação do "Imposto Sindical", pagas, recolhidas e aplicadas na forma estabelecida neste capítulo.

Art. 579. O imposto sindical é devido, por todos aqueles que participarem de uma determinada categoria econômica ou profissional, ou de uma profissão liberal, em favor do sindicato representativo da mesma categoria ou profissão ou inexistindo este na conformidade do disposto no art. 581.

${ }^{34}$ CLT (Decreto-Lei no 5.452, de 10.5.1943) - REDAÇÃO ORIGINAL:

Art. 515. As associações profissionais deverão satisfazer os seguintes requisitos para serem reconhecidas como sindicatos:

a) reunião de um terço, no mínimo, de empresas legalmente constituídas, sob a forma individual ou de sociedade, se se tratar de associação de empregadores; ou de um terço dos que integrem a 
Esse modelo corporativo, de inspiração italiana, também foi adotado:

(1) na FRANÇA, pelo MARECHAL PÉTAIN (1940-1945);

(2) na ARGENTINA, por JUAN DOMINGO PERÓN (1943-1952);

(3) no MÉXICO, por LÁZARO CÁRDENAS (1934-1940);

(4) na ESPANHA, por FRANCISCO FRANCO (1939-1973); e

(5) em PORTUGAL, por ANTÓNIO DE OLIVEIRA SALAZAR (com o Estatuto do Trabalho Nacional - Decreto-Lei 23.048 de 23.9.1933 até 1974).

\section{A Constituição de 1946 e a reação dos sindicatos ao controle do poder público}

Três anos após a promulgação da CLT, o país experimentou o advento do período democrático com a Constituição de 1946.

Quanto ao tema do sindicalismo, a nova Constituição expressamente previa a liberdade de associação sindical.

Destacava, apenas, que caberia à lei a regulação de sua constituição, sua representação legal nas convenções coletivas e o exercício de funções delegadas do Poder Público. ${ }^{35}$

Não houve alteração substancial, uma vez que se entendia que a legislação trabalhista anterior - inclusive aquela que significava intervenção direta no funcionamento dos sindicatos - continuava em pleno vigor sob o pano de fundo da nova Constituição. ${ }^{36}$

mesma categoria ou exerçam a mesma profissão liberal se se tratar de associação de empregados ou de trabalhadores ou agentes autônomos ou de profissão liberal;

b) duração não excedente de dois anos para o mandato da diretoria;

c) exercício do cargo de presidente por brasileiro nato, e dos demais cargos de administração e representação por brasileiros.

Parágrafo único. O ministro do Trabalho, Indústria, e Comércio poderá, excepcionalmente, reconhecer como sindicato a associação cujo número de associados seja inferior ao terço a que se refere a alínea a.

Art. 518. O pedido de reconhecimento será dirigido ao ministro do Trabalho, Indústria e Comércio, instruído com exemplar ou cópia autenticada dos estatutos da associação.

${ }^{35}$ Constituição de 1946:

Art 159 - É livre a associação profissional ou sindical, sendo reguladas por lei a forma de sua constituição, a sua representação legal nas convenções coletivas de trabalho e o exercício de funções delegadas pelo Poder Público.

${ }^{36}$ Veja-se um dos "considerandos" do Decreto 23.046, de 7.5.1947, que suspendeu o funcionamento da "Confederação dos Trabalhadores do Brasil":

(...) 
Dessa forma, a ideologia corporativa do Estado Novo não sofreu abalos no que tange aos sindicatos.

Cite-se, como exemplo, o DL 9.070, de 15.3.1946, anterior à Constituição de 1946, que já recuperava a legislação do período do Estado Novo.

Referido decreto regulava a greve reduzindo de tal forma sua força que praticamente a neutralizava.

Os anos que se seguiram, contudo, representaram as tentativas de o movimento sindical se livrar dos sindicatos de fachada e dos pelegos, para a retomada da combatividade dos anos 1910 e 1920.

Com o recrudescimento da posição política de controle e intervenção do GOVERNO VARGAS, multiplicaram-se as tentativas de superar a estrutura sindical oficial por meio da criação de representações horizontais de trabalhadores, longe da restrição da categoria profissional.

De alguma forma, os ventos democráticos que alimentaram os trabalhos constituintes de 1946 já sopravam antes da promulgação do texto, embora ainda enfrentando a repressão estatal.

Em 1945, por exemplo, écriado o MUT(MOVIMENTOUNIFICADORDOS TRABALHADORES), ligado ao PCB (PARTIDO COMUNISTA BRASILEIRO) que recém-conquistara a legalização e a anistia ampla e irrestrita.

O maior objetivo do MUT era a superação da estrutura sindical vertical, por meio da defesa do retorno da combatividade das representações e da liberdade sindical.

No entanto, o Departamento Federal de Segurança Pública impugnou o registro do MUT sob o argumento de serem ilícitos e perigosos seus atos.

O MINISTÉRIO DO TRABALHO intervém no processo e o registro do MUT é definitivamente cancelado em 1946 pelo PRESIDENTE EURICO GASPAR DUTRA (Decreto 23.046, de 7.5.1947).

Em realidade, por trás da cassação do registro do MUT, está a luta política com o PCB que passou a apoiar as greves após a democratização e a criticar o GOVERNO DUTRA, notadamente depois da ruptura do Governo com a UNIÃO SOVIÉTICA.

CONSIDERANDO que a legislação vigente se harmoniza com a letra e o espírito se harmoniza com a letra e o espírito do art. 159 da Constituição Federal, pois, se o legislador constituinte assegurou a liberdade de associação sindical deixou, entretanto, à legislação ordinária a regulamentação da forma de sua constituição; 


\section{O sindicalismo no segundo governo de Vargas}

O Decreto 23.046/1947 é a maior prova de que, mesmo no novo regime democrático, o Governo não abriria mão do tratamento interventivo e corporativo aos sindicatos e não toleraria sua configuração como associações de discurso político.

O argumento oficial para cassação desses novos formatos de sindicatos horizontais era de que eles não se enquadravam na estrutura sindical oficial e nem mesmo representavam categorias profissionais. ${ }^{37}$

Haveria, portanto, uma proibição de criação das chamadas "Uniões Sindicais" como restou claro dos "considerandos" do Decreto 23.046/1947.

Dessa forma, o quadro político e sua relação com o sindicalismo pareciam bastante claros:

- a redemocratização do país incrementou a mobilização dos trabalhadores que tentaram retomar a combatividade por meio da superação do "peleguismo" e da convocação das greves, várias delas com o apoio do PCB.

Assim, a política interventiva e de controle dos sindicatos que interessava ao ESTADO NOVO também passou a interessar ao GOVERNO DUTRA, pelo pretenso perigo político que representaria a liberdade sindical (sindicatos fora da estrutura oficial) e sua pluralidade.

\footnotetext{
${ }^{37}$ Decreto no 23.046, de 7.5.1947:

CONSIDERANDO que é dever precípuo do Governo manter associações sindicais rigorosamente dentro de suas finalidades legais e afastadas dos movimentos políticos e sociais;

CONSIDERANDO que na sistemática da Consolidação das leis do Trabalho, aprovada pelo Decreto-lei no 5.452 , de 1 de maio de 1943, as associações profissionais que integram o quadro sindical brasileiro são, apenas os sindicatos, federações e confederações, aqueles como órgãos de primeiro grau e estas como associações sindicais de grau superior (arts. 511, 512, 533, 535, 558, 570 e 577);

CONSIDERANDO que na consonância do disposto na mesma Consolidação das Leis do Trabalho, somente as associações profissionais constituídas por atividades ou profissionais idênticas, similares ou conexas poderão ser reconhecidas como sindicatos (artigos 511, 515, 517, 52, 189 e 558);

(...)

CONSIDERANDO que a consolidação das leis do trabalho desconhece, como órgãos sindicais, as chamadas "Uniões Sindicais", pois na forma do quanto estatui, somente assegura condições de vida aos sindicatos, federações ou confederações instituídas pelo modo e nas condições previstas no Título V da mencionada Consolidação;

CONSIDERANDO que as associações civis não podem, no seu funcionamento, avocar o direito de representação e defesa de interesses das respectivas categorias profissionais, conferidos exclusivamente às entidades sindicais, legalmente reconhecidas, como acontece com as "Uniões Sindicais";
} 
A reação às "Uniões Sindicais" e o enfraquecimento do PCB e de seu braço trabalhista eram imperativos que se colocavam diante do quadro que se apresentava:

- em 1951, houve 200 paralisações;

- em 1952, foram 300; e

- em 1953, quase 800 movimentos de greve.

O quadro de enfrentamento prossegue até o GOLPE DE 1964 por meio de pulsação cruel.

O MOVIMENTO SINDICAL tentando arrebentar as amarras ao controle estatal especialmente:

(1) por meio das greves, ${ }^{38}$ tais como a dos marítimos de $6.1953 ; ;^{39} \mathrm{e}$

(2) com a criação de representações fora da estrutura sindical da CLT; ${ }^{40}$

O GOVERNO, por sua vez, atuava restringindo essas iniciativas por meio de política de repressão.

A chegada de JOÃO GOULART ao MINISTÉRIO DO TRABALHO, após a greve dos marítimos de 1953, representou um alívio nas relações entre sindicatos e Governo.

Para contornar o contexto de embate, JOÃO GOULART, usando de seu prestígio entre os sindicatos e a "carta em branco" dada por GETÚLIO VARGAS:

- atende as reivindicações dos grevistas;

- encerra a política de perseguição aos comunistas; e

- estabelece um amplo projeto de reformas sociais. ${ }^{41}$

JOÃO GOULART também deu voz ao pleito do aumento em $100 \%$ do salário mínimo (de 1.200 para 2.400 cruzeiros), uma das principais bandeiras do movimento sindical da época.

Essa providência começou a ser estudada em 1.1954.

Resultou em forte reação do empresariado, dos militares, ${ }^{42}$ dos opositores políticos (UDN) e mesmo do então MINISTRO DA FAZENDA, OSWALDO ARANHA, que sempre defendera política de contenção de gastos.

\footnotetext{
${ }^{38}$ Por exemplo, a greve dos 300 mil de 25.3.1953 a 23.4.1953 na INDÚSTRIA TÊXTIL FRANCISCO MATARAZZO que deu origem a um Comando Intersindical do qual nasceu o PACTO DE UNIDADE INTERSINDICAL (PUI), organização à margem da estrutura sindical oficial.

${ }^{39}$ Resultou na queda de JOSÉ DE SEGADAS VIANA do Ministério do Trabalho, Indústria e Comércio.

${ }^{40}$ Por exemplo, do MUT, da Confederação Geral dos Trabalhadores do Brasil - CGTB - , a União dos Trabalhadores Agrícolas do Brasil, a 1르 Liga Camponesa em 1955.

${ }^{41}$ Dentre providências de sua política de aproximação com o movimento dos trabalhadores está a convocação do $1^{\circ}$ Congresso Brasileiro de Previdência Social, a política de financiamento de casas e de empréstimos pelo Instituto de Aposentadoria e Pensões dos Bancários (IAPB).

42 "Manifesto do Coronéis": 82 oficiais afirmavam que um trabalhador não poderia ganhar o mesmo salário que um segundo-tenente do Exército.
} 
O clima de instabilidade política com o temor de uma "REPÚBLICA SINDICALISTA" chegou ao seu ápice com o encaminhamento da proposta de aumento no início de fevereiro de 1954.

A situação de JOÃO GOULART ficou insustentável e rumou para sua renúncia em 23.2.1954.

Nessa mesma data, curiosamente, houve também a exoneração do então MINISTRO DA GUERRA, O GENERAL CIRO DO ESPÍRITO SANTO CARDOSO.

Em 1.5 do mesmo ano, o PRESIDENTE GETÚLIO VARGAS anunciou o novo salário mínimo.

Paralelamente, o movimento sindical tentava ainda superar a organização formal da estrutura da CLT por meio da criação espontânea de outros nichos de representação, especialmente por meio de uniões intersindicais horizontais. ${ }^{43}$

A memória desses eventos ajuda a compreender as dificuldades políticas enfrentadas pelo movimento sindical ao longo da história no rumo de maior liberdade e autonomia.

\section{Sindicalismo no período do regime militar}

O GOLPE DE 1964 representou a radicalização da repressão ao movimento de trabalhadores, notadamente porque um dos seus apelos era a ideia do combate à "REPÚBLICA SINDICALISTA", que se atribuía como objetivo do PRESIDENTE JOÃO GOULART.

Houve a intervenção em mais de 2.000 sindicatos, com a cassação de sua direção, prisões e exílios.

A política de desarticulação, repressão e controle dos sindicatos também resultou em nova estratégia de arrocho salarial, no fim do regime de estabilidade no emprego e na Lei 4.330, de 1.6.1964 (a famosa lei antigreve).

A Constituição de 1967 (art. 15944) e a Emenda Constitucional 1 de 17.10.1969 (art. $166^{45}$ ), do ponto de vista do direito positivo, reafirmaram

\footnotetext{
${ }^{43}$ Como foi o caso do PACTO DE UNIDADE E AÇÃO (PUA) de 6.1961 (organização intersindical formada principalmente por ferroviários, marítimos e portuários e que era considerada ilegal pelo Ministério do Trabalho). Após 1964, seus líderes OSVALDO PACHECO e RAFAEL MARTINELLI foram presos. E, outro exemplo, foi o COMANDO GERAL DOS TRABALHADORES, de 6.1962 (que também sofreu perseguição e sofreu com a desmobilização).

${ }^{44}$ Constituição de 1967:

Art 159 - É livre a associação profissional ou sindical; a sua constituição, a representação legal nas convenções coletivas de trabalho e o exercício de funções delegadas de Poder Público serão regulados em lei.
} 
a liberdade de associação profissional e sindical, tal como havia feito a Constituição de 1946.

Do ponto de vista do movimento sindical, os problemas relativos à desmobilização e perseguição continuaram ainda com mais vigor.

Há, entretanto, reações dos trabalhadores como a criação do MOVIMENTO INTERSINDICAL ANTIARROCHO (MIA), em 10.1967.

A repressão do novo regime continuou a ser dura, como ocorreu na greve de Contagem de 16.4.1968 e na comemoração de 1.5.1968, na Praça da Sé em São Paulo.

O movimento sindical apenas volta com força no final da década de 1970 com a retomada das reivindicações por reajuste salarial e pelo início do processo de reabertura política. ${ }^{46}$

Em 8.1981 o tema da UNICIDADE/PLURALIDADE SINDICAL volta a ser discutido durante a 1a CONFERÊNCIA DA CLASSE TRABALHADORA (Conclat), em Praia Grande (SP).

As discussões dessa conferência resultaram, dois anos depois, na fundação da CENTRAL ÚNICA DOS TRABALHADORES (CUT), em 1983.

Em 1986 é fundada a CENTRAL GERAL DOS TRABALHADORES (CGT).

\section{A década de 1990 e o novo modelo das centrais sindicais}

A Constituição de 1988 (CF) é o marco do processo de redemocratização do país.

No campo do direito sindical, a CF trouxe inegáveis avanços como

- a proibição de que lei possa exigir autorização do Estado para a fundação de sindicatos; e

- a vedação à intervenção do Poder Público no funcionamento dessas entidades. ${ }^{47}$

\footnotetext{
${ }^{45}$ Emenda Constitucional no 1/1969:

Art. 166. É livre a associação profissional ou sindical; a sua constituição, a representação legal nas convenções coletivas de trabalho e o exercício de funções delegadas de poder público serão regulados em lei.

${ }^{46} \mathrm{O}$ início dessa retomada é a greve na Saab-Scania em São Bernardo do Campo em 12.5.1978.

${ }^{47}$ Constituição de 1988:

Art. $8^{\circ}(\ldots)$

I - a lei não poderá exigir autorização do Estado para a fundação de sindicato, ressalvado o registro no órgão competente, vedadas ao Poder Público a interferência e a intervenção na organização sindical;
} 
Contudo, a mesma distorção ou contradição, já observada desde a Constituição de 1934, se manteve com a confirmação da UNICIDADE SINDICAL, ${ }^{48}$ em um contexto constitucional de proteção à liberdade de associação sindical. ${ }^{49}$

Por outro lado, a CLT foi considerada plenamente em vigor e compatível com a CF de $1988^{50}$ e, portanto, válida sua estrutura sindical corporativa. Manteve-se, por exemplo, a necessidade de registro do MINISTÉRIO DO TRABALHO.

Assim sendo, tal como ocorreu em 1946, o momento de redemocratização foi mais importante do ponto de vista da ação política dos sindicatos do que em relação à abertura normativa do ordenamento jurídico.

É nesse sentido que pode ser entendida a criação de várias CENTRAIS SINDICAIS no início da década de $1990 .{ }^{51}$

As CENTRAIS SINDICAIS encamparam a luta das antigas UNIÕES SINDICAIS.

Luta essa pela criação de formatos de representação espontâneos, fora da estrutura formal imposta pela CLT, na sequência de uma mentalidade inovadora que trouxe um novo norte ao sindicalismo brasileiro.

O movimento sindical moderno, representado pelas CENTRAIS SINDICAIS, se coloca contrário ao corporativismo de nossa tradição.

Tal corporativismo trouxe manipulação e peleguismo, quando não descambou para a simples ideologia radical e extremista, sem apelo na eficácia de suas negociações e lutas.

Essa nova etapa, plasmada principalmente no livro UM PROJETO PARA O BRASIL (1993), busca um sindicalismo mais pragmático, apartidário,

\footnotetext{
${ }^{48}$ Constituição de 1988:

Art. $8^{\circ}$ É livre a associação profissional ou sindical, observado o seguinte:

(...)

II - é vedada a criação de mais de uma organização sindical, em qualquer grau, representativa de categoria profissional ou econômica, na mesma base territorial, que será definida pelos trabalhadores ou empregadores interessados, não podendo ser inferior à área de um Município; ${ }^{49}$ Constituição de 1988:

Art. 8 o É livre a associação profissional ou sindical, observado o seguinte:

${ }^{50}$ Veja-se, por exemplo, RMS no 24.069, relator Ministro Marco Aurélio, DJU 24.6.2005; RE n⿳o 222.285-Agr, relator Ministro Carlos Velloso, DJU 22.3.2002; RE no 180.745, relator Ministro Sepúlveda Pertence, DJU 8.5.1998; MI no 144, relator Ministro Sepúlveda Pertence, DJ 28.5.1993.

${ }^{51}$ FORÇA SINDICAL em 8.3.1991; CENTRAL AUTÔNOMA DOS TRABALHADORES (CAT) em 1995; SOCIAL DEMOCRACIA SINDICAL (SDS) em 1997; NOVA CENTRAL SINDICAL DOS TRABALHADORES (NCST) já em 6.2005; UNIÃO GERAL DOS TRABALHADORES (UGT), 7.2007; e CENTRAL DOS TRABALHADORES E TRABALHADORAS DO BRASIL (CTB), 12.2007.
} 
baseado na pluralidade do movimento sindical e na defesa da autonomia e liberdade dos sindicatos e na negociação democrática para alcançar seus objetivos, com independência política do Governo, mas com proximidade suficiente para levar reivindicações dos trabalhadores.

A forma de garantir a espontaneidade do movimento e sua total autonomia política era representar a classe trabalhadora, mesmo que fora dos limites da categoria profissional que, durante décadas, foi importante instrumento de restrição e boicote tácito à força do movimento sindical.

\section{Notas conclusivas da parte histórica}

Após tudo isso, podemos constatar que a fundação das CENTRAIS SINDICAIS é continuidade do processo histórico do sindicalismo brasileiro.

Vejam-se suas premissas:

(01) o movimento sindical nasceu com forte conotação ideológico-política, com discurso anarquista;

(02) o tom das primeiras reuniões e dos primeiros sindicatos anunciava já o potencial do movimento operário como força política capaz de pautar o Estado;

(03) a suposta ameaça que os sindicatos representavam fez o Estado desenvolver uma política de enfrentamento, tentando controlá-lo (Decreto 19.770/31) e repreendê-lo (Lei 1.641/07);

(04) a vitória de VARGAS (Revolução de 1930) levou os direitos dos trabalhadores e sua pauta de reivindicações para o centro do Governo e os mais diversos direitos trabalhistas passaram a ser reconhecidos a partir da Constituição de 1934;

(05) a postura garantista de VARGAS não viria sem preço: a intenção do Governo era manter os sindicatos próximos, submetidos à regulamentação do Estado, funcionando a partir do registro e da autorização do Poder Público;

(06) com isso, VARGAS teria instrumentos para controlar tais sindicatos, retirando de seu discurso o tom ideológico e anarquista, o que era assegurado por meio da política do "peleguismo";

(07) VARGAS adotou, ainda, dois instrumentos de controle sindical bastante eficazes:

(a) a UNICIDADE SINDICAL, com o Decreto 24.694/34 (apesar dos esforços da frente católica na constituinte de 1934 - art. 120, parágrafo único) e;

(b) a exigência de sindicatos de representação de categorias profissionais; 
(08) Com essas medidas, o Governo obteve a diluição, a desmobilização, o enfraquecimento e a segurança de discurso apolítico dos sindicatos, o que viabilizou sua intenção de controlar o movimento sindical;

(09) A Constituição de 1937 e o Estado Novo confirmaram e aprimoraram a política de controle dos sindicatos (DL 1.402/39), apesar da garantia da liberdade de associação sindical. A intervenção na formação e funcionamento dos sindicatos se deu por meio do corporativismo, mantendo-se a unidade sindical e sua separação entre categorias profissionais;

(10) Com a instituição da JUSTIÇA DO TRABALHO, fez-se necessária a aprovação de uma CONSOLIDAÇÃO DAS LEIS TRABALHISTAS, o que veio a ocorrer em 1943. Antes disso, entretanto, o DL 2.377/40 criava o imposto sindical para sustentar a estrutura sindical oficial;

(11) Com a proibição de tom político ou ideológico no discurso dos sindicatos e a manutenção da estrutura sindical oficial, o controle do ESTADO NOVO era ilimitado;

(12) Iniciava-se, após, um longo processo político caracterizado pelos esforços do movimento sindical de se desvincular das amarras impostas pelo Poder Público principalmente por meio:

(a) da mitigação da representação por categoria profissional; e

(b) do enfraquecimento da estrutura corporativa a partir da fundação e criação de entidades paralelas e horizontais;

(13) O processo de redemocratização e a Constituição de 1946, apesar de não alterarem substancialmente a previsão normativa (DL 9.070/46 e Decreto 23.046/47), não evitaram que os sindicatos tentassem retomar seu controle e se libertar dos pelegos que ameaçavam sua autonomia;

(14) O novo tom combativo resultou na convocação de inúmeras greves e a tentativa de criação das chamadas "UNIÕES SINDICAIS" (MUT, PUI, CGTB, PUA), entidades representativas não vinculadas apenas a uma categoria profissional e localizadas à margem da estrutura sindical oficial;

(15) As bandeiras sindicais causavam apreensão entre os opositores do Governo (UDN): militares, empresariado, refratários dos comunistas e, ainda, parte do Governo contrária ao aumento dos gastos públicos;

(16) A turbulência social chegou ao ápice na gestão de JOÃO GOULART no MINISTÉRIO DO TRABALHO (1953-1954), que atendeu várias das reivindicações operárias (inclusive o aumento de 100\% do salário mínimo), causando o temor com a "REPÚBLICA SINDICALISTA";

(17) Com o Golpe de 1964, a repressão dos sindicatos e as perseguições aos seus dirigentes se intensificaram e o movimento representativo dos trabalhadores foi, novamente, sufocado (Lei 4.330/64); 
(18) Somente no final da década de 1970, os sindicatos alcançaram certa mobilização para combater o arrocho salarial que se acumulava desde os anos 1960, especialmente com as greves convocadas no ABC Paulista, com a Conclat em 1981 e a fundação da CUT já em 1983;

(19) A CF de 1988 repetiu, de certa maneira, a contradição normativa das Constituições passadas: previsão de LIBERDADE DE ASSOCIAÇÃO SINDICAL convivendo com o princípio da UNICIDADE SINDICAL;

(20) Para o movimento dos trabalhadores, era preciso ainda mitigar a UNICIDADE SINDICAL e reduzir a importância da representação por categorias profissionais que, no passado, haviam despolitizado o movimento, tornando-o técnico e letárgico;

(21) Os tempos eram outros e parecia ser mais eficaz a mitigação do tom combativo e radicalmente ideológico por uma postura negocial e pragmática, visando conquistas concretas para os trabalhadores;

(22) É nesse contexto que nasceram as CENTRAIS SINDICAIS principalmente nas décadas de 1990 e 2000

- entidades horizontais, fora da estrutura corporativa da CLT, livres das limitações da representação de categoria profissional e, portanto, com mais liberdade e autonomia para negociar e democratizar a forma interna de sua gestão.

O conhecimento e a reflexão sobre o processo histórico da relação entre SINDICALISMO e PODER PÚBLICO é imperioso para o exame da Lei 11.648, de 31.3.2008, que reconheceu as CENTRAIS SINDICAIS.

\section{Direito}

\section{Constitucionalidade da Lei 11.648, de 31.3.2008}

\section{Introdução}

A Lei 11.648, de 31.3.2008, foi o resultado de um longo período de negociações com o Governo no sentido de se garantir instrumental normativo que fortalecesse a autonomia sindical no país.

A CF de 1988 exige leitura historicamente adequada de maneira a compatibilizar, nesse início de século XXI, a UNICIDADE SINDICAL e com a LIBERDADE DE ASSOCIAÇÃO SINDICAL. 
Duas posições que, em outras Cartas Políticas, pareceram contraditórias devem ser harmonizadas, em decorrência do processo histórico-político, com a mitigação da estrutura sindical corporativa prevista na CLT.

O reconhecimento das CENTRAIS SINDICAIS, por meio da mencionada lei, impõe a tarefa de, sem abandonar a pirâmide sindical da CLT, admitir a existência dessas CENTRAIS, produtos de um processo histórico.

\section{ADI no 4.067. Pontos da petição inicial}

Em 9.4.2008, o PARTIDO DEMOCRATAS (DEM) ingressou com ação alegando a inconstitucionalidade dos seguintes dispositivos da Lei 11.648/2008:

(1) art. $1^{\mathrm{o}}, \mathrm{II} ;{ }^{52}$

(2) art. $3^{\mathrm{o} .53}$

(3) a nova redação do art. 589, II, " b", e seus $\S \S 1^{\circ}$ e $2^{\circ}$ da CLT; ${ }^{54}$

(4) nova redação dada ao art. 593 da CLT. ${ }^{55}$

${ }^{52}$ Lei no 11.648, de 31.3.2008:

Art. 1o A central sindical, entidade de representação geral dos trabalhadores, constituída em âmbito nacional, terá as seguintes atribuições e prerrogativas:

(...)

II - participar de negociações em fóruns, colegiados de órgãos públicos e demais espaços de diálogo social que possuam composição tripartite, nos quais estejam em discussão assuntos de interesse geral dos trabalhadores.

${ }^{53}$ Lei no 11.648, de 31.3.2008:

Art. 3ำ A indicação pela central sindical de representantes nos fóruns tripartites, conselhos e colegiados de órgãos públicos a que se refere o inciso II do caput do art. $1^{\circ}$ desta Lei será em número proporcional ao índice de representatividade previsto no inciso IV do caput do art. $2^{2}$ desta Lei, salvo acordo entre centrais sindicais.

${ }^{54}$ Lei no 11.648 , de 31.3.2008:

Art. 5o Os arts. 589, (...) da Consolidação das Leis do Trabalho - CLT, aprovada pelo Decreto-Lei no 5.452 , de $1^{\circ}$ de maio de 1943 , passam a vigorar com a seguinte redação:

Art. 589. (...)

II - para os trabalhadores:

(...)

b) $10 \%$ (dez por cento) para a central sindical;

(...)

$\S 1$ ㅇ O sindicato de trabalhadores indicará ao Ministério do Trabalho e Emprego a central sindical a que estiver filiado como beneficiária da respectiva contribuição sindical, para fins de destinação dos créditos previstos neste artigo.

$\S 2^{\circ}$ A central sindical a que se refere a alínea b do inciso II do caput deste artigo deverá atender aos requisitos de representatividade previstos na legislação específica sobre a matéria. (NR)

${ }^{55}$ Lei $\mathrm{n}^{\mathrm{o}}$ 11.648, de 31.3.2008: 
Argumenta a Inicial:

(1) a CONTRIBUIÇÃO SINDICAL é contribuição parafiscal do tipo contribuição de interesse de categorias profissionais (CF, art. 149):

- deve ter destinação a interesse específico da categoria profissional;

(2) não pode parcela da arrecadação ser destinada às CENTRAIS SINDICAIS:

- seriam entidades que não teriam como finalidade precípua a defesa de interesse de uma categoria profissional;

(3) a destinação dos recursos de tributos a entidades não estatais é exceção:

- somente pode ser prevista na $\mathrm{CF}$, tal como ocorre no seu art. 8o, IV; ${ }^{56}$

(4) somente os sindicatos são entidades aptas a representar os trabalhadores em questões judiciais e administrativas (CF, art. 8ㅇ, III):

- não pode a lei ampliar essa delegação a outros entes não previstos na CF.

\section{A constitucionalidade da Lei 11.648, de 31.3.2008}

\section{(1) As centrais sindicais como realidade inafastável}

As questões levantadas na INICIAL têm, como pressuposto, modelo abstrato-jurídico já superado pela realidade e pela experiência histórica do sindicalismo brasileiro.

Como visto acima, as CENTRAIS SINDICAIS são imperativos históricos da luta do sindicalismo brasileiro para se libertar das amarras do controle do Estado.

As CENTRAIS SINDICAIS constituem-se no "aggiornamento" do movimento sindical.

Este movimento institui novos formatos de maneira a garantir, com plenitude, a liberdade de associação sindical e a autonomia de seu discurso, dois objetivos previstos pela CF de 1988 (art. 8o, caput, $\mathrm{I}^{57}$ ).

Art. 5 Os arts. (...) e 593 da Consolidação das Leis do Trabalho - CLT, aprovada pelo Decreto-Lei no 5.452, de 1ำ de maio de 1943, passam a vigorar com a seguinte redação:

Art. 593. As percentagens atribuídas às entidades sindicais de grau superior e às centrais sindicais serão aplicadas de conformidade com o que dispuserem os respectivos conselhos de representantes ou estatutos.

${ }^{56}$ Inconstitucional o novo art. 589, II, " $\mathrm{b}$ ”, da CLT, também o seriam, por arrastamento, os $\S \S 1^{\circ} \mathrm{e}$ 2o do mesmo art. 589 e o art. 593.

${ }^{57}$ Constituição de 1988: 
As CENTRAIS SINDICAIS integram o processo de amadurecimento e atualização do sindicalismo, razão pela qual não poderiam estar descritas na CF de 1988.

São fruto de movimentação do sindicalismo brasileiro, com início incipiente contemporâneo à CF de 1988 e com consolidação posterior à sua promulgação.

O processo histórico impõe uma compreensão contemporânea da expressão "sindicato" constante da CF.

Uma interpretação restrita e limitada depõe contra outras regras constitucionais ( $\mathrm{CF}$, art. 8oㅡ. I e V) e importa em ver o processo histórico com olhos e compreensão congelados pelo passado.

De fato, as CENTRAIS SINDICAIS são um dado da realidade de hoje.

Negá-las ou rejeitar o seu reconhecimento institucional seria uma enviesada forma de não autorizar a sua fundação e seu funcionamento, o que se choca com a liberdade assegurada pela CF (art. 8o, I).

Essa regra assegura a liberdade de "associação profissional ou sindical" e proíbe a exigência de autorização do Estado para a sua fundação, sua interferência e a sua intervenção na organização sindical.

De fato, essa seria a maneira mais traiçoeira de vedar liberdade e autonomia às entidades sindicais, pois legitimaria típica cartilha de intervenção e interferência.

De mais a mais, a medida significaria claro desrespeito à ideia de livre associação (CF, art. 5ํㅡ, XVII, XVIII e XXI' ${ }^{58}$ ).

Mas, há mais.

$\mathrm{O}$ art. 8o, V, determina que "ninguém será obrigado a filiar-se ou a manter-se filiado a sindicato".

Art. 8o É livre a associação profissional ou sindical, observado o seguinte:

I - a lei não poderá exigir autorização do Estado para a fundação de sindicato, ressalvado o registro no órgão competente, vedadas ao Poder Público a interferência e a intervenção na organização sindical;

${ }^{58}$ Constituição de 1988:

Art. $5^{\circ}(\ldots)$

XVII - é plena a liberdade de associação para fins lícitos, vedada a de caráter paramilitar;

XVIII - a criação de associações e, na forma da lei, a de cooperativas independem de autorização, sendo vedada a interferência estatal em seu funcionamento;

(...)

XXI - as entidades associativas, quando expressamente autorizadas, têm legitimidade para representar seus filiados judicial ou extrajudicialmente; 
Isso significa dizer que se trata de um direito fundamental do trabalhador optar por se associar a um sindicato, por não se associar ou, ainda, por preferir a representação, em seu nome, das CENTRAIS SINDICAIS.

Pretender que as CENTRAIS SINDICAIS não possam participar de "fóruns, colegiados de órgãos públicos e demais espaços de diálogo social" mesmo que em número proporcional ${ }^{(59)}$, importa em restringir o princípio da liberdade de associação sindical, afirmado na CF (art. 8º, caput, e inciso V).

Ademais, a CF assegura a participação dos trabalhadores nos colegiados dos órgãos públicos em que seus interesses profissionais ou previdenciários sejam objeto de discussão e deliberação (art. $\left.10^{60}\right)$.

Obviamente, essa garantia dada se refere não a um direito dos sindicatos - ditos aqui como aqueles pertencentes à estrutura oficial, mas um direito dos trabalhadores, que podem preferir a representação por outras entidades do movimento.

Garantir-se-á esse direito através de ampla participação dos trabalhadores nesses colegiados, sem qualquer limitação quanto à natureza da entidade sindical que se assente à mesa de negociação.

O MINISTRO MARCO AURÉLIO, com sua experiência de origem, enfrentou o art. 10 da $\mathrm{CF}$ em termos precisos:

(...)

A discussão diz respeito à participação de trabalhadores e empregadores em órgãos públicos e aí o constituinte teve o cuidado de deslocar regência da matéria para artigo autônomo, não inseriu em inciso no artigo $8^{\circ}$, que cuida do sistema sindical, não vinculando, portanto, esta participação à intermediação da entidade sindical e a distribuição do que arrecadado a título de contribuição sindical.

E a representatividade aqui para mim é indiscutível e eu penso que o Tribunal deverá inclusive evoluir tendo em conta nova jurisprudência, para admitir que estas centrais, consubstanciando associações de classe de âmbito nacional, tenham legitimação para Adin, para o processo subjetivo.

(...)

\footnotetext{
${ }^{59}$ Art. 1, II, e art. 3o da Lei 11.648/2008.

${ }^{60}$ Constituição de 1988:

Art. 10. É assegurada a participação dos trabalhadores e empregadores nos colegiados dos órgãos públicos em que seus interesses profissionais ou previdenciários sejam objeto de discussão e deliberação.
} 
As CENTRAIS SINDICAIS, portanto, estão em perfeita compatibilidade e harmonização com os pressupostos de democracia, transparência e autonomia que a CF 1988 garantiu.

Por isso que, ao se utilizar o termo "sindicato", cabe ao intérprete afinado com tais pressupostos modernos compreender entidades sindicais seja da estrutura oficial da CLT, seja as entidades horizontais de representação.

\section{(2) A compatibilidade com a Convenção 87 da OIT}

Há, ainda, o fato relevante da compatibilidade com o direito sindical internacional a partir da CONVENÇÃO 87 da OIT.

Trata-se de CONVENÇÃO da OIT que ainda não foi ratificada pelo Brasil, especialmente porque sempre se tratou a UNICIDADE SINDICAL de maneira rigorosa sob o viés do estrangulamento das outras formas espontâneas de representação dos trabalhadores.

A CONVENÇÃO dispõe sobre:

(a) a liberdade de associação sindical; ${ }^{61} \mathrm{e}$

(b) a autonomia dessas entidades em sua fundação e funcionamento em relação ao Poder Público (artigo 3ํㅜㄹ).

A Lei 11.648/2008 aproxima os princípios constantes da CONVENÇÃO com a prática institucional no Brasil, ao reconhecer as entidades horizontais de representação.

Em outras palavras, com a lei, o país não só reafirma os princípios constantes da CONVENÇÃO como dá plena aplicação ao seu artigo 11 (proteção do direito de sindicalização). ${ }^{63}$

\footnotetext{
${ }^{61}$ Convenção no 87 , relativa à liberdade sindical e à proteção do direito de sindicalização, da OIT: Artigo $2^{\circ}$

Os trabalhadores e os empregadores, sem nenhuma distinção e sem autorização prévia, têm o direito de constituir as organizações que estimem convenientes, assim como o de filiar-se a estas organizações, com a única condição de observar os estatutos das mesmas.

${ }^{62}$ Convenção no 87 , relativa à liberdade sindical e à proteção do direito de sindicalização, da OIT:

Artigo 3o

1. As organizações de trabalhadores e de empregadores têm o direito de redigir seus estatutos e regulamentos administrativos, o de eleger livremente seus representantes, o de organizar sua administração e suas atividades e o de formular seu programa de ação.

2. As autoridades públicas deverão abster-se de toda intervenção que tenha por objetivo limitar este direito ou entorpecer seu exercício legal.

${ }^{63}$ Convenção no 87 , relativa à liberdade sindical e à proteção do direito de sindicalização, da OIT:
} 


\section{(3) O sentido de "categoria profissional" para o sindicalismo moderno}

A INICIAL dedica grande parcela de sua argumentação para apontar o equívoco da destinação de parcela da contribuição sindical a uma entidade que não atuaria para categoria profissional específica.

Trata-se de afirmação produzida por interpretação menor da CF.

É calçada no corporativismo e no fechamento sindical que marcou o período do Estado Novo e da CLT, neste ponto.

Recorde-se que a divisão estrita dos sindicatos em rigorosas categorias profissionais foi um mecanismo da política interventiva de VARGAS para desmobilizar, enfraquecer e despolitizar o próprio movimento sindical.

Não é esse o objetivo da CF (art. 8o) que, ao contrário, pretende reforçar e prestigiar a atuação das entidades sindicais.

A exigência de vinculação a categoria profissional precisa ser lida de maneira compatível com os novos tempos, reconhecendo, inclusive, as conquistas alcançadas para categoriais profissionais específicas obtidas pela atuação das CENTRAIS SINDICAIS.

Em outras palavras, as CENTRAIS SINDICAIS também são entidades de representação das categoriais profissionais vinculadas e associadas ao seu quadro e, por isso, atuam no interesse dessas categorias quando agem nas respectivas áreas.

Tanto é assim que as CENTRAIS SINDICAIS vêm crescendo mais rapidamente do que as entidades sindicais de grau superior da pirâmide da CLT na medida em que se mostram aos sindicatos com atuação mais eficaz na negociação de pautas trabalhistas e de reivindicações dos trabalhadores. ${ }^{64}$

Assim, as CENTRAIS SINDICAIS representam, sem prejuízo e exclusão de sindicatos específicos, diversas categorias profissionais.

\section{PARTE II}

\section{PROTEÇÃO DO DIREITO DE SINDICALIZAÇÃO}

\section{Artigo 11}

Todo Membro da Organização Internacional do Trabalho para o qual esta Convenção esteja em vigor, obriga-se a adotar todas as medidas necessárias e apropriadas para garantir aos trabalhadores e aos empregadores o livre exercício do direito de sindicalização.

${ }^{64}$ Em fevereiro de 2008 a Força Sindical, por exemplo, tinha 689 sindicatos a ela filiados; a CUT mantinha 1.626 sindicatos. Em dezembro de 2011 a CUT apresentava 2.168 sindicatos e a Força Sindical, 1.717. Apesar de existir diferença, torna-se claro que o crescimento da principal central sindical foi bem mais acentuado do que da principal entidade sindical da pirâmide. 
Isto reforça a ideia de que não há qualquer empecilho para que, ao lado das entidades sindicais de grau superior da estrutura oficial, possam também ser beneficiárias de parcela da arrecadação da contribuição sindical, forma gestada para a sustentação financeira das representações sindicais.

A Lei 11.648/2008, em realidade, garantiu igualdade entre as CENTRAIS SINDICAIS e as entidades sindicais da estrutura oficial.

Todas elas representantes dos trabalhadores e que, por atuarem em contexto nacional, representam diversas categorias profissionais específicas a depender da mesa de negociação, fórum ou colegiado em que se façam presentes.

Assim, portanto, não há qualquer incompatibilidade entre a Lei 11.648/2008 e os arts. 8o, IV, e 149 da CF.

Por outro lado, a tese da interpretação restrita ao termo "categoria profissional" não se sustenta pela própria dinâmica histórica de arrecadação e aplicação dos recursos da contribuição sindical.

\section{(4) A redistribuição da contribuição sindical}

Cabe breve apanhado histórico com o fim de demonstrar as diversas divisões dos recursos arrecadados pelo imposto sindical, transformado em contribuição com a CF de $1988 .{ }^{65}$

Verifica-se, principalmente, que a parcela dos recursos destinada agora às CENTRAIS SINDICAIS era, no regime anterior, valor que iria para a "CONTA ESPECIAL EMPREGO E SALÁRIO", que também não era aplicada em benefício de uma categoria profissional específica.

Vejamos.

\section{(A) O regime inicial do imposto sindical}

O IMPOSTO SINDICAL foi criado no Brasil com o DL 2.377, de 8.7.1940, alguns anos antes da promulgação da CLT.

Eis seu art. 1ㅇ:

\footnotetext{
${ }^{65}$ RE no 180.745 , relator Ministro Moreira Alves, DJ 8-5-1998. CF, art. 8o, IV, e art. 149.
} 
Art. 1ํㅗㄴ As contribuições devidas aos sindicatos pelos que participem das categorias econômicas ou profissionais representadas pelas referidas entidades, consoante as alíneas a do art. 38 e f do art. 3o do decreto-lei n. 1.402, de 5 de julho de 1939 (2), serão, sob a denominação de "imposto sindical", pagas e arrecadadas pela forma estabelecida neste decreto-lei.

O IMPOSTO SINDICAL era devido por todos os trabalhadores, sindicalizados ou não, em favor do sindicato reconhecido pelo Governo (art. $\left.2^{\underline{o}}\right){ }^{66}$ no valor correspondente a um dia de trabalho (art. 3o, a). ${ }^{67}$

Seu pagamento era anual e descontado na folha de salário (art. $4^{\circ}$ ). ${ }^{68}$

Da importância arrecadada com o imposto, 20\% seria destinada às associações profissionais de grau superior (art. 15), ${ }^{69}$ remanescendo o saldo com os sindicatos respectivos.

A princípio, o Poder Público não participava da distribuição e, sequer, se envolvia na destinação dos recursos.

Caberia ao empregador repassar, em abril, o valor retido na folha de salário em março de cada ano ao sindicato correspondente (art. $8^{\circ}$ ).$^{70}$

Após, o DL 4.298, de 14.5.1942, dispôs sobre o recolhimento e aplicação do imposto sindical.

A sistemática de distribuição dos recursos se altera com essa nova normativa.

\section{${ }^{66}$ Decreto-Lei no 2.377, de 8.7.1940:}

Art. $2^{\circ} \mathrm{O}$ imposto sindical é devido, por todos aqueles que participarem de uma determinada categoria econômica ou profissional, em favor da associação profissional legalmente reconhecida como sindicato representativo da mesma categoria.

${ }^{67}$ Decreto-Lei no 2.377, de 8.7.1940:

Art. $3^{\circ} \mathrm{O}$ imposto sindical será pago de uma só vez, anualmente, e consistirá:

a) na importância correspondente à remuneração de um dia de trabalho, para os empregados, qualquer que seja a forma da referida remuneração;

${ }^{68}$ Decreto-Lei no 2.377, de 8.7.1940:

Art. 4 Os empregadores são obrigados a descontar na folha de pagamento de seus empregados, relativa ao mês de março de cada ano, o imposto sindical por estes devido aos respectivos sindicatos.

${ }^{69}$ Decreto-Lei no 2.377, de 8.7.1940:

Art. 15. Da importância anual da arrecadação do imposto sindical será deduzida, em favor das associações profissionais de grau superior, a percentagem de $20 \%$ (vinte por cento), na forma que estabelecer o Ministro do Trabalho, Indústria e Comércio.

${ }^{70}$ Decreto-Lei no 2.377, de 8.7.1940:

Art. $8^{\circ} \mathrm{O}$ recolhimento do imposto sindical descontado pelos empregadores aos respectivos empregados será efetuado no mês de abril de cada ano, diretamente, ao sindicato a cuja categoria pertencerem, ou aos estabelecimentos bancários pelo mesmo sindicato indicados, observadas as instruções do Ministro do Trabalho, Indústria e Comércio. 
Da importância arrecadada com o imposto, 20\% seriam destinados às associações sindicais de grau superior, cabendo $15 \%$ à federação e $5 \%$ à confederação (art. $\left.4^{\circ}\right){ }^{71}$

Outra novidade foi a criação de uma conta especial denominada "FUNDO SOCIAL SINDICAL", à qual se destinariam "20\% do imposto sindical relativo a cada sindicato" ${ }^{72}$

O DL também estabelecia a aplicação dos recursos recebidos pelos sindicatos como assistência médica e dentária, assistência judiciária, escolas de alfabetização, cooperativas de crédito e de consumo, etc. ${ }^{73}$

O "FUNDO SOCIAL SINDICAL" seria gerido pela COMISSÃO DO IMPOSTO SINDICAL (CIS), com sede no MINISTÉRIO DO TRABALHO, INDÚSTRIA E COMÉRCIO e integrado por representantes indicados pelo Governo e pelas confederações patronais e de trabalhadores. ${ }^{74}$

\section{${ }^{71}$ Decreto-Lei no 4.298, de 14.5.1942:}

Art. 4º Da importância anual da arrecadação do imposto sindical será deduzida, em favor das associações sindicais de grau superior, a percentagem de $20 \%$, cabendo $15 \%$ à Federação a que se acharem filiados os Sindicatos e os restantes $5 \%$ à respectiva Confederação.

\section{${ }^{72}$ Decreto-Lei no ${ }^{-298}$, de 14.5.1942:}

Art. $5^{\circ}$ Das importâncias recolhidas de acordo com o art. 2º os estabelecimentos bancários ali referidos transferirão a uma conta especial, denominada "Fundo Social Sindical", 20\% do imposto sindical relativo a cada sindicato.

\section{${ }^{73}$ Decreto-Lei no ${ }^{\circ} .298$, de 14.5.1942:}

Art. 7o $\mathrm{O}$ imposto sindical, feitas as deduções de que tratam os artigos $4^{\circ}$ e $5^{\circ}$, será aplicado pelos sindicatos:

(...)

II. De empregados:

a) em agências de colocação, na forma das instruções que forem expedidas pelo Ministro do Trabalho, Indústria e Comércio;

b) na assistência à maternidade;

c) em assistência médica e dentária;

d) em assistência judiciária;

e) em escolas de alfabetização e prevocacionais;

f) em cooperativas de crédito e de consumo;

g) em colônias de férias;

h) em bibliotecas;

i) em finalidades esportivas;

j) nas despesas decorrentes dos encargos criados pelo presente decreto-lei.

${ }^{74}$ Decreto-Lei no ${ }^{4}$.298, de 14.5.1942:

Art. 9o O "Fundo Social Sindical" será gerido e aplicado pela Comissão do Imposto Sindical em objetivos que atendam aos interesses gerais da organização sindical nacional.

Art. 11. Compete à Comissão do Imposto Sindical:

a) gerir o "Fundo Social Sindical" criado pelo presente decreto-lei;

b) organizar o plano sistemático da aplicação do "Fundo Social Sindical";

c) fiscalizar a aplicação do imposto sindical, expedindo normas que se fizerem necessárias; 


\section{(B) O regime da CLT para o imposto sindical}

CONSOLIDAÇÃO DAS LEIS DO TRABALHO (1943) reafirma o regime de distribuição dos valores arrecadados a título de imposto sindical.

O texto original confirma a destinação de $20 \%$ às entidades sindicais de grau superior (15\% às federações e $5 \%$ às confederações - art. 589). ${ }^{75}$

Mantém a destinação de $20 \%$ ao "FUNDO SOCIAL SINDICAL" (art. 590), ${ }^{76}$ para ser aplicado "em objetivos que atendam aos interesses gerais da organização sindical nacional" (Art. 594)..$^{77}$

As regras referentes à aplicação do imposto pelos sindicatos e sobre a COMISSÃO DO IMPOSTO SINDICAL permanecem inalteradas (arts. 592, 595, 596 e 597).

Após, o DL 8.740, de 19.1.1946, altera diversos dispositivos da CLT, dentre os quais o art. 594 que atribuía a gestão do "FUNDO SOCIAL SINDICAL" à CIS.

A gestão do FUNDO passa para COMISSÃO NACIONAL DE SINDICALIZAÇÃO. ${ }^{78}$

O DL 8.739/46 expressamente prevê que as despesas do pessoal, material e encargos da própria comissão sairão do "FUNDO SOCIAL SINDICAL". ${ }^{79}$

As percentagens de destinação dos valores arrecadados permaneceram as mesmas com o Decreto-Lei 8.740/46:

(a) $20 \%$ para as entidades sindicais de grau superior; e

(b) $20 \%$ ao "FUNDO SOCIAL SINDICAL" (art. 589 não foi alterado).

d) baixar as instruções de que trata o parágrafo único do art. 7으,

e) resolver as dúvidas suscitadas no cumprimento deste decreto-lei.

${ }^{75}$ Decreto-Lei no ${ }^{0}$.452, de 1ㅇ.5.1943 (CLT):

Art. 589. Da importância anual da arrecadação do imposto sindical será deduzida, em favor das entidades sindicais de grau superior, a percentagem de $20 \%$ (vinte por cento), cabendo $15 \%$ (quinze por cento) à Federação coordenadora das categorias a que corresponderem os Sindicatos e os restantes $5 \%$ (cinco por cento) à respectiva confederação.

${ }^{76}$ Decreto-Lei no 5.452, de 10.5.1943 (CLT):

Art. 590. Das importâncias recolhidas de acordo com o art. 586, o Banco do Brasil transferirá a uma conta especial, denominada "Fundo Social Sindical", 20\% (vinte por cento) do imposto sindical relativo a cada sindicato.

${ }^{77}$ Decreto-Lei no 5.452, de 1o.5.1943 (CLT):

Art. 594. O "Fundo Social Sindical" será gerido e aplicado pela Comissão do Imposto Sindical em objetivos que atendam aos interesses gerais da organização sindical nacional.

${ }^{78}$ Criada pelo Decreto-Lei 8.739, de 19.1.1946 (PRESIDÊNCIA JOSÉ LINHARES).

${ }^{79}$ Decreto-Lei no 8.739 , de 19.1.1946:

Art. 10. As despesas do pessoal, material e encargos diversos da Comissão Nacional de Sindicalização correrão por conta de verba própria destacada do "Fundo Social Sindical" e prevista em orçamento anual votado pela Comissão. 
Alguns dias depois, em 15.2.1946, o novo Presidente, EURICO GASPAR DUTRA, edita o DL 8.987-A. ${ }^{80}$

Suspende a execução dos Decretos-Leis 8.739 e 8.740 (PRESIDENTE JOSÉ LINHARES) e restabelece "a vigência dos dispositivos revogados ou derrogados pelos referidos decretos-leis". ${ }^{81}$

No mesmo ano, o PRESIDENTE EURICO GASPAR DUTRA edita o DL 9.615, de 20.8.1946, por meio do qual altera o art. 594 da CLT e prevê que o " 'Fundo Social Sindical' será gerido e aplicado pela Comissão do Imposto Sindical em objetivos que atendam aos interesses gerais da organização sindical nacional ou à assistência social aos trabalhadores"”. ${ }^{82}$

\section{(C) Alterações na aplicação dos recursos do imposto sindical após 1964}

Depois de pontuais alterações, ${ }^{83}$ a Lei 4.589 , de 11.12.1964, promoveu a extinção da COMISSÃO DO IMPOSTO SINDICAL ${ }^{84}$ e alterou o regime de aplicação dos 20\% destinados ao "FUNDO SOCIAL SINDICAL".

Essa legislação fixou que essa parcela de $20 \%$ passaria a constituir uma "conta especial denominada 'Emprego e Salário'". 85

\footnotetext{
${ }^{80}$ Publicado no Diário Oficial da União em 23.2.1946.

${ }^{81}$ Decreto-Lei no 8.987-A, de 15.2.1946:
}

Art. 1o Fica suspensa a execução dos Decretos-leis ns. 8.739 e 8.740, ambos de 19 de janeiro de 1946, e restabelecida a vigência dos dispositivos legais revogados ou derrogados pelos referidos decretos-leis.

Parágrafo único. Ficam de nenhum efeito os atos que tenham sido expedidos ou praticados na conformidade dos aludidos decretos-leis.

${ }^{82}$ Decreto-Lei no 9.615, de 20.8.1946:

Art. 1 o O art. 594, da Consolidação das Leis do Trabalho, passa a vigorar com a seguinte redação: "Art. 594. O "Fundo Social Sindical” será gerido e aplicado pela Comissão do Imposto Sindical em objetivos que atendam aos interesses gerais da organização sindical nacional ou à assistência social aos trabalhadores".

${ }^{83}$ Lei no 3.022, de 19.12.1956 e Lei no 4.140, de 21.09.1962;

${ }^{84}$ Lei no 4.589, de 11.12.1964:

Art. 1o São extintas a Comissão do Imposto Sindical e a Comissão Técnica de Orientação Sindical e feitas, na estrutura administrativa do Ministério do Trabalho e Previdência Social e nas atribuições dos seus órgãos, as alterações constantes desta Lei.

${ }^{85}$ Lei no 4.589, de 11.12.1964:

Art. 18. os vinte por cento do Imposto Sindical, que formam o "Fundo Social Sindical", passarão a constituir uma conta especial denominada "Emprego e Salário" que será utilizada, no exercício de 1965, exclusivamente nas despesas de instalação e funcionamento dos órgãos criados ou transformados pela presente Lei, no pagamento do pessoal transferido dos seus cargos em comissão e funções gratificadas. 
Tal CONTA, no exercício de 1965, serviria unicamente para as despesas de instalação e funcionamento dos órgãos criados ou transformados pela lei. ${ }^{86}$

Em seguida, estabelece a lei que, a partir de 1966, o percentual de $20 \%$ será acrescido ao orçamento do então MINISTÉRIO DO TRABALHO E PREVIDÊNCIA SOCIAL, "como reforço de suas verbas ordinárias". ${ }^{87}$

Para a execução dessas providências, a Lei 4.589/64 alterou os arts. 590 e 591 e revogou os arts. 595, 596 e 597, todos da CLT.

Em 1965, a Lei 4.923, de 23.12, deu mais exatidão à destinação dos $20 \%$ da “CONTA ESPECIAL EMPREGO E SALÁRIO".

Pela nova sistemática:

(a) 2/3 dos valores constantes da "CONTA ESPECIAL EMPREGO E SALÁRIO" serão dirigidos ao "FUNDO DE ASSISTÊNCIA AO DESEMPREGADO" (criado pelo art. 6o da mesma lei) ${ }^{88} \mathrm{e}$

(b) $1 / 3$ seria utilizado para completar a instalação e funcionamento dos órgãos criados pela Lei 4.589/64 (especialmente o reaparelhamento das Delegacias Regionais do Trabalho) ${ }^{89}$

\footnotetext{
${ }^{86}$ Lei $\mathrm{n}^{\mathrm{0}}$ 4.589, de 11.12.1964:
}

Art. 2o São criados o Departamento Nacional de Emprego e Salário, o Conselho Superior do Trabalho Marítimo e as Delegacias Regionais do Trabalho do Distrito Federal e do Estado da Guanabara, e transformada a atual Divisão de Higiene e Segurança do Trabalho, em Departamento Nacional de Segurança e Higiene do Trabalho.

${ }^{87}$ Lei no 4.589 , de 11.12.1964:

Art. 18. (...)

Parágrafo único. A partir do exercício financeiro de 1966 e enquanto vigorar o atual sistema concernente ao Imposto Sindical, o Banco do Brasil transferirá ao Tesouro Nacional, os vinte por cento da conta especial "Emprego e Salário", para serem acrescidos ao orçamento do Ministério do Trabalho e Previdência social, como reforço de suas verbas ordinárias.

88 O "Fundo de Assistência ao Desempregado" foi criado para atender ao custeio do plano de assistência aos trabalhadores que "após 120 (cento e vinte) dias consecutivos de serviço na mesma empresa, se encontrarem desempregados ou venham a se desempregar, por dispensa sem justa causa ou por fechamento total ou parcial da empresa". (art. 5o da Lei oㅡ 4.923, de 23.12.1965).

${ }^{89}$ Lei no 4.923, de 23.12.1965:

Art. $6^{\circ}-$ Para atender ao custeio do plano a que se refere o art. $5^{\circ}$, fica o Poder Executivo autorizado a constituir um Fundo de Assistência ao Desempregado, pelo qual exclusivamente correrão as respectivas despesas.

Parágrafo único. A integralização do Fundo de que trata este artigo se fará conforme dispuser o regulamento de que trata o art. 5:

(...)

b) por 2/3 (dois terços) da conta "Emprego e Salário" a que alude o art. 18 da Lei nº 4.589, de 11 de dezembro de 1964.

Art. 9o - Ressalvada a decisão que vier a ser tomada consoante o disposto no art. 16 da Lei no 4.589, de 11 de dezembro de 1964, a conta especial "Emprego e Salário" de que trata o seu art. 18, inclusive os saldos transferidos de um para outro exercício, continuará a ser utilizada, nos exercícios de 1966 e seguintes, pela forma nele prevista, revogado seu parágrafo único, com exclusão, porém, das despesas com vencimentos e vantagens fixas do pessoal, já incluídas, 
O regime de distribuição somente veio a ser alterado com a Lei 6.386, de 9.12.1976, que modificou diversos dispositivos da CLT, dentre eles, do art. 580 ao art. 592.

Eis a nova distribuição:

(a) $5 \%$ para a confederação correspondente;

(b) $15 \%$ para a federação;

(c) $60 \%$ para o sindicato respectivo;

(d) 20\% para a "CONTA ESPECIAL EMPREGO E SALÁRIO".90

Essa distribuição perdurou até 2008, quando foi modificada pela lei ora em exame (Lei 11.648).

A Lei 11.648/2008 fez uma única mudança na distribuição:

- Reduziu para 10\% a parcela da "CONTA ESPECIAL EMPREGO E SALÁRIO" e destinou $10 \%$ às CENTRAIS SINDICAIS, de acordo com a indicação dos trabalhadores.

Assim, a nova divisão da arrecadação passou a ser:

(a) $5 \%$ para a confederação correspondente;

(b) $15 \%$ para a federação correspondente;

(c) $60 \%$ para o sindicato respectivo;

(d) $10 \%$ para a "CONTA ESPECIAL EMPREGO E SALÁRIO"; e

(e) $10 \%$ para a central sindical.

de acordo com o art. 19 da mesma lei, na lei orçamentária do exercício de 1966 e observado o disposto nos parágrafos deste artigo.

$\S 1^{\circ}$ - da conta de que trata este artigo, destinar-se-ão:

a) $2 / 3$ (dois terços) ao custeio do "Fundo de Assistência ao Desemprego", de acordo com o disposto no art. 6 o da presente lei;

b) $1 / 3$ (um terço), para completar a instalação e para funcionamento dos órgãos criados, transformados ou atingidos pela mencionada Lei $\mathrm{n}^{\circ} 4.589$, com as alterações referidas no art. $7^{\circ} \stackrel{0}{\circ}$ desta Lei, e, em especial, para o reaparelhamento das Delegacias Regionais do Trabalho com o respectivo Serviço de Coordenação dos Órgãos Regionais, e das Delegacias de Trabalho Marítimo, assim como para complementar a confecção e distribuição de Carteiras Profissionais, de modo que se lhes assegure a plena eficiência dos serviços, notadamente os da Inspeção do Trabalho, com a mais ampla descentralização local dos mesmos.

${ }^{90}$ CLT com a redação dada pela Lei no ${ }^{0}$.386, de 9.12.1976:

Art. 589. Da importância da arrecadação da contribuição sindical serão feitos os seguintes créditos pela Caixa Econômica Federal, na forma das instruções que forem expedidas pelo Ministro do Trabalho:

I - 5\% (cinco por cento) para a confederação correspondente;

II $-15 \%$ (quinze por cento) para a federação;

III $-60 \%$ (sessenta por cento) para o sindicato respectivo;

IV - 20\% (vinte por cento) para a "Conta Especial Emprego e Salário". 


\section{(D) Novo regime de divisão da arrecadação da contribuição sindical}

A nova divisão dos valores não atingiu as entidades sindicais formadoras da estrutura sindical oficial prevista na CLT.

Tal divisão dispôs de parcela absorvida pelo Governo Federal.

Foi o próprio PODER EXECUTIVO que propôs a redistribuição de sua parcela (do MINISTÉRIO DO TRABALHO).

Desde o Decreto-lei 4.298, de 14.5.1942, ${ }^{91}$ tais valores não são destinados aos Sindicatos.

São aplicados ao funcionamento dos órgãos criados pela Lei 4.589/64 e ao "FUNDO DE ASSISTÊNCIA AO DESEMPREGO".

Assim, tal destinação atingia, de forma indireta, todos os trabalhadores, independentemente de atuação ou vinculação sindical e, principalmente, da categoria profissional em que se inseriam.

Desta forma, os $10 \%$ que, por iniciativa do Poder Executivo, foram extraídos da "CONTA ESPECIAL DE EMPREGO E SALÁRIO" já não tinham, desde $1942,{ }^{92}$ qualquer utilização com base no critério restrito da categoria profissional do trabalhador.

Demonstra-se, assim, que os valores arrecadados com a contribuição sindical não guardam qualquer relação intrínseca com a categoria profissional ou com o sindicato que a representa.

Se a vinculação à categoria profissional fosse tão rígida, a própria destinação de parcela da arrecadação à "CONTA ESPECIAL EMPREGO E SALÁRIO" seria uma opção legislativa inconstitucional, como bem salientou o MINISTRO MARCO AURÉLIO no debate em plenário.

Também as CENTRAIS SINDICAIS representam tantas categorias profissionais quanto foram os sindicatos a ela ligados.

\section{Estado do julgamento no STF}

O relator é o MINISTRO JOAQUIM BARBOSA.

Seu voto, de 24.6.2009 e reafirmado em 10.3.2010, enfrenta dois pontos:

\footnotetext{
${ }^{91}$ Com o FUNDO SOCIAL SINDICAL.

${ }^{92}$ Decreto-Lei 4.298, de 14-5-1948.
} 
(a) art. 1ํㅡㄴ II e art. 3ํ da Lei 11.648/2008:

- conferiu-lhes interpretação conforme para entender pela constitucionalidade, desde que a representação das centrais sindicais em fóruns tripartites, conselhos e colegiados de órgãos públicos não afastasse a participação dos sindicatos.

Eis parte do voto:

\section{(...)}

Assim, eu interpreto o caput do $1^{\text {o }}$ e o respectivo inciso II, bem como o artigo 3ㅜ, da Lei 11.648, de modo a fixar que a representação geral dos trabalhadores e a participação nas negociações em fóruns, colegiados de órgãos públicos e demais espaços de diálogo social que possuam composição tripartite, nos quais estejam em discussão assuntos de interesse geral dos trabalhadores, não prejudicam a competência outorgada pela Constituição às entidades sindicais de base ou de grau superior, ou seja, os sindicatos, as confederações e as federações.

Em outras palavras, as entidades sindicais não podem ser substituídas pelas centrais.

(...)

(b) redação do art. 589, II, b, §§ 1ํ e 2o e art. 593 da CLT:

- deu pela inconstitucionalidade dos dispositivos.

Lê-se no voto:

\section{(...)}

A contribuição anual compulsória, chamada imposto sindical, foi instituída para auxiliar o custeio das entidades que compõem o sistema de representação sindical, pois tem por amparo o interesse das categorias profissionais e econômicas na manutenção da estrutura que permite a sua representação eficiente no campo das relações do trabalho.

Tal representação é qualificada - vale dizer - não se refere à defesa ampla dos interesses do trabalhador, refere-se, sim, à representação normativa obrigatória, CF artigos 8o, III, e IV.

Como visto, as centrais sindicais não fazem parte da estrutura sindical, não obstante a sua importância como agentes nas negociações de interesses dos trabalhadores.

(...) 
Os MINISTROS CESAR PELUSO e RICARDO LEWANDOWSKI acompanharam (24.6.2009).

\section{[Representatividade]}

Note-se que os votos admitiram a constitucionalidade da Lei que reconheceu a legitimidade das CENTRAIS SINDICAIS e sua representatividade institucional.

Os três MINISTROS admitiram a participação das CENTRAIS SINDICAIS nos fóruns de negociação, sem prejuízos da "competência (...) outorgada às entidades sindicais de base ou de grau superior".

Foram, assim, preservados, com "interpretação conforme", os dispositivos da lei referentes ao reconhecimento da legitimidade e representatividade das CENTRAIS SINDICAIS.

Leia-se no voto do MINISTRO JOAQUIM BARBOSA:

(...) quase todas as entidades sindicais, a maioria dos sindicatos, muitas das federações e algumas das confederações estão filiados a uma das 5 centrais, e seguem as suas diretrizes, como bem foi frisado aqui da tribuna.

E de fato, elas comandam o movimento sindical. Eis um paradoxo que resulta do artigo $8^{\circ}$ da $\mathrm{CF}$, cuja alteração se impõe para adequar-se à realidade sindical brasileira.

$(\ldots)$

Também os MINISTROS MARCO AURÉLIO, CARMEN LÚCIA E EROS GRAU acompanharam o RELATOR em relação à interpretação conforme dirigida aos arts. 1으, II, e 3o da lei.

Divergiram no outro ponto.

Votaram pela constitucionalidade da nova redação dos arts. 589, II, " $\mathrm{b}$ ", $\S \S 1^{\circ}$ e 2으, e 593 da CLT - redistribuição da parcela de $20 \%$ que era, antes, destinada, em sua totalidade, ao Governo Federal.

Os MINISTROS GILMAR MENDES, CELSO DE MELLO, ROSA WEBER e AYRES BRITTO (este último com vistas do processo) ainda não se manifestaram.

O MINISTRO LUIZ FUX não vota por suceder o MINISTRO EROS GRAU, que já se manifestou. 
O MINISTRO DIAS TOFFOLI está impedido.

Como se constata, já há maioria quanto aos art. 1ํㅡㄴ II e art. $3^{\circ}$ da Lei 11.648/2008 (constitucionalidade, com "interpretação conforme" - 6 votos).

Assim, a maioria do TRIBUNAL já reconheceu a institucionalidade e legitimidade, pela lei, das CENTRAIS SINDICAIS, sem prejuízo da ação das demais entidades, as quais, em grande número, conforme afirmou o MINISTRO JOAQUIM BARBOSA, "estão filiadas a uma das 5 centrais, e seguem as suas diretrizes ... [que] de fato, (...) comandam o movimento sindical".

[Redistribuição de parcela dos recursos]

Há, de outra via, empate (3 votos pela constitucionalidade e 3 votos pela inconstitucionalidade) dos dispositivos que se referem à participação das CENTRAIS SINDICAIS na arrecadação da contribuição sindical.

O principal argumento da inconstitucionalidade diz respeito à eventual natureza jurídica de contribuição compulsória para o interesse de categoria profissional ou econômica atribuída à contribuição sindical.

Foi visto, acima, que a parcela destinada pela lei às CENTRAIS SINDICAIS (novo art. 589, II, " $\mathrm{b}$ ”, da CLT) foi extraída de recursos geridos pelo Poder Público por meio da "CONTA ESPECIAL EMPREGO E SALÁRIO".

Tal CONTA, como se viu, consiste em verba orçamentária carimbada destinada à CONTA ESPECIAL DE EMPREGO E SALÁRIO, gerida pelo MINISTÉRIO DO TRABALHO para suas despesas e para políticas de assistência ao desemprego.

Não se confundam essas políticas com o SEGURO-DESEMPREGO, atendido pelo FUNDO DE AMPARO AO TRABALHADOR (FAT), ${ }^{93}$ cujas fontes de recurso são as contribuições ao PROGRAMA DE INTEGRAÇÃO SOCIAL $(P I S)^{94}$ e ao PROGRAMA DE FORMAÇÃO DO PATRIMÔNIO DO SERVIDOR PÚBLICO (Pasep). ${ }^{95}$

Repita-se que parcela de $20 \%$ da contribuição sindical, antes da lei, destinava-se integralmente à "CONTA ESPECIAL EMPREGO E SALÁRIO", sem relação alguma com categoria profissional ou econômica.

\footnotetext{
${ }^{93} \mathrm{CF}$, art. 239.

${ }^{94}$ Lei Complementar 7, de 7-9-1970.

${ }^{95}$ Lei Complementar 8, de 3-12-1970.
} 
Assim, a premissa do argumento pela inconstitucionalidade da redistribuição não se sustenta.

Os recursos da "CONTA ESPECIAL EMPREGO E SALÁRIO", como se demonstrou, não se destinam, desde de 1942, a "auxiliar o custeio das entidades que compõem o sistema de representação sindical".

Auxilia e custeia, isto sim, o MINISTÉRIO DO TRABALHO, pois integra uma de suas rubricas orçamentárias.

É da verba da "CONTA ESPECIAL EMPREGO E SALÁRIO" do MINISTÉRIO DO TRABALHO (20\% da contribuição sindical) que a Lei extraiu a metade $(10 \%)$ para as CENTRAIS SINDICAIS.

Lembre-se, mesmo assim, que as CENTRAIS SINDICAIS atuam também na defesa dos interesses das categorias profissionais e econômicas - da forma como fazem as entidades sindicais de grau superior -, pois defendem os interesses dos sindicatos a ela filiados, como reconheceu o próprio RELATOR: "de fato, elas comandam o movimento sindical".

$\mathrm{Na}$ verdade, a atribuição de recursos às CENTRAIS SINDICIAIS atende à destinação maior da contribuição sindical - a sustentação financeira das representações do movimento.

Insista-se.

A MAIORIA do TRIBUNAL já admitiu o reconhecimento, pela Lei, da representatividade das CENTRAIS SINDICAIS.

Tal premissa impõe, como consequência necessária, assegurar, como constitucional, o mecanismo, criado pela Lei, de sustentação econômica das CENTRAIS SINDICAIS.

E mais, a solução, dada pela Lei, não altera, em nada, a participação, nos recursos da contribuição sindical, das demais entidades do movimento sindical.

É o Governo Federal que, por iniciativa própria, abriu mão de parte dos recursos destinada ao MINISTÉRIO DO TRABALHO.

\section{[Tribunal de Contas da União]}

Ponto relevante foi suscitado, na discussão, pelo MINISTRO GILMAR MENDES.

Acenou para a eventual fiscalização do TRIBUNAL DE CONTAS DA UNIÃO (TCU) quanto à utilização desses recursos. 
O projeto de lei enviado pelo Poder Executivo não tinha nenhuma disposição a respeito do tema.

Na tramitação do PL 1.990/2007, a CÂMARA DOS DEPUTADOS aprovou tal exigência, tendo sido aprimorado pelo SENADO FEDERAL. ${ }^{96}$

Estava no "AUTÓGRAFO" enviado à PRESIDÊNCIA DA REPÚBLICA.

Art. $6^{\circ}$ Os sindicatos, as federações e as confederações das categorias econômicas ou profissionais ou das profissões liberais e as centrais sindicais deverão prestar contas ao Tribunal de Contas da União sobre a aplicação dos recursos provenientes das contribuições de interesse das categorias profissionais ou econômicas, de que trata o art. 149 da Constituição Federal, e de outros recursos públicos que porventura venham a receber.

No entanto, o PRESIDENTE DA REPÚBLICA o vetou.

Eis as Razões do Veto:

O art. 6ำ viola o inciso I do art. 8 da Constituição da República, porque estabelece a obrigatoriedade dos sindicatos, das federações, das confederações e das centrais sindicais prestarem contas ao Tribunal de Contas da União sobre a aplicação dos recursos provenientes da contribuição sindical. Isto porque a Constituição veda ao Poder Público a interferência e a intervenção na organização sindical, em face do princípio da autonomia sindical, o qual sustenta a garantia de autogestão às organizações associativas e sindicais.

Não obstante isso, seria salutar e republicano a prestação de contas ao TCU.

\footnotetext{
${ }^{96}$ A exigência foi sugerida na CÂMARA por meio da Emenda de Plenário no 28 dos Deputados ANTONIO CARLOS PANNUNZIO (líder do PSDB) e JOSÉ CARLOS ALELUIA (vice-líder do DEM) em 17-10-2007 (Diário da Câmara dos Deputados, 18 out. 2007, p. 55304) que, a princípio, somente submetia as CENTRAIS SINDICAIS à fiscalização do TCU.

No SENADO, entretanto, nova redação foi sugerida para englobar não só as CENTRAIS SINDICAIS, mas também sindicatos, federações e confederações das categorias econômicas ou profissionais ou das profissões liberais (Emenda oㅡ 5 do SENADO, correspondente à emenda ํo 22 - Parecer no 1.151 de 2007 da Comissão Diretora). A Emenda do SENADO foi aprovada pela CÂMARA em 11-3-2008, encaminhado pelo parecer do Relator, DEPUTADO VICENTINHO (PT/SP).
} 
A fiscalização do TCU, mesmo de entidades com personalidade jurídica de direito privado, é consequência natural do recebimento de valores arrecadados a título de obrigação tributária, tal como ocorre com o pagamento compulsório da contribuição sindical.

Não se trata apenas de uma obrigação imposta pela CF de $1988,{ }^{97}$ mas, acima de tudo, um dever institucional advindo dos princípios da legalidade, impessoalidade, moralidade, publicidade e eficiência indicados no art. 37, caput, também da CF.

Não se trata de intervenção do Estado no funcionamento dessas entidades de representação dos trabalhadores, uma vez que tais valores são repassados para serem utilizados em finalidades específicas, já indicadas na legislação (CLT, art. 592).

De mais a mais, o próprio STF vem reconhecendo o necessário horizonte de fiscalização do TCU, ${ }^{98}$ mesmo em relação a entidades de personalidade jurídica de direito privado.

\section{Conclusão}

Por isso tudo, o reconhecimento da constitucionalidade dos dispositivos se impõe.

Afirma-se, assim, a plena constitucionalidade dos arts. 1으. II; 3ㅇ; e 5o, este que dá nova redação ao art. 589, II, "b", $\S \S 1^{\circ}$ e $2^{\circ}$ e art. 593 da CLT, todos da Lei 11.648/2008.

Brasília - DF, 24 de fevereiro de 2012.

NELSON A. JOBIM

$\mathrm{OAB} / \mathrm{DF}$ n 23.650

\section{RODRIGO DE OLIVEIRA KAUFMANN}

$\mathrm{OAB} / \mathrm{DF}$ no 23.866

\footnotetext{
${ }^{97} \mathrm{CF}$, art. 70, parágrafo único.

${ }^{98}$ Veja, por exemplo, a decisão que reconheceu a competência do TCU para proceder a tomada de contas especial de administradores e demais responsáveis por dinheiros, bens e valores públicos das entidades integrantes da administração indireta, não importando se prestadoras de serviço público ou exploradoras de atividade econômica (MS no 25.092, relator Ministro Carlos Velloso, DJU 17-3-2006). No caso, reconheceu-se a competência do TCU em face de sociedade de economia mista.
} 